\title{
Laboratory, in situ and full-scale load tests to assess flood embankment stability on peat
}

\author{
C. ZWANENBURG* and R. J. JARDINE†
}

\begin{abstract}
The low submerged unit weights of peats usually lead to low effective self-weight stresses, stiffnesses and undrained shear strengths. These features, in combination with high compressibility, a propensity to creep and the uncertain effects of fibrous inclusions, make foundation stability hard to assess reliably. It is usual to apply high safety, or strong material reduction, factors in foundation design. However, over-conservatism can lead to undesirable environmental and financial costs. This paper describes full-scale field tests conducted on peat, with and without pre-loading, at Uitdam on the borders of Lake Markermeer, north of Amsterdam. The experiments investigated the peat layers' consolidation behaviour and their response under loading, including full shear failure. Noting the complex final test geometries and the large displacements developed, simple numerical analyses were undertaken to help interpret the failures within a Tresca and 'consolidated undrained shear strength' framework. The trials that included modest pre-loading developed large vertical consolidation strains (up to 35\%) and significant bearing capacity improvements. The field experiments provide a rich resource for testing advanced numerical techniques. They also allowed a range of practical characterisation techniques to be assessed and calibrated for flood dyke applications.
\end{abstract}

KEYWORDS: embankment; failure; foundations; full-scale tests; laboratory tests; organic soils

\section{BACKGROUND}

A range of approaches exist to characterise operational undrained shear strengths for stability analyses of embankments on soft clay; see for example Jardine (2002). Greater difficulties are encountered with peats, which are harder to sample and often manifest exceptionally high $\phi^{\prime}$ and pore pressure ratios in undrained laboratory tests, but not clear failure: see Yamaguchi et al. (1985), Den Haan \& Kruse (2006) or Zwanenburg et al. (2012). Low resistances, potential rate effects, possible anisotropy and fibrous inclusions also hinder in situ shear strength test interpretation; Landva (2007) and Boylan et al. (2011).

Nevertheless, great lengths of embankments have been built on peats. One Dutch example is the $30-\mathrm{km}$ flood dyke which runs along Lake Markermeer, with the typical section shown in Fig. 1. The dyke has been raised progressively from medieval times up to 1916 with low-grade fill. Its crest now stands $4.5 \mathrm{~m}$ above the low-lying, mainly agricultural 'polder' land it protects. Current national assessment guidelines indicate low $(\approx 1.6 \mathrm{kPa})$ operational 'equivalent undrained shear strengths' for peat in the polder region that rise to $\approx 40 \mathrm{kPa}$ in the substantially compressed peat under the crest. Analyses undertaken with these parameters indicate inadequate stability and imply the need for substantial strengthening works that would impact negatively on the area of outstanding beauty. This paper describes comprehensive testing that was undertaken to help gauge the foundation shear strengths that could be mobilised under field conditions. Measurements are reported of collapse loads, pore pressure development and dissipation, as well as ground movements, from both short-term and longer-term loading tests. Suites of laboratory and in situ tests are also reported

Manuscript received 1 April 2014; revised manuscript accepted 4 February 2015.

Discussion on this paper closes on 1 September 2015, for further details see $p$. ii.

$*$ Deltares, Delft, The Netherlands.

$\dagger$ Imperial College, London, UK. that allow comparisons to be drawn with field consolidation trends and operational undrained shear strengths. The latter are interpreted with the aid of simple Tresca-based finiteelement analyses. The field data offer a resource for further studies in which more advanced, fully coupled, large strain analyses involving more representative constitutive models could be evaluated. Considerable scope exists for considering the impacts of anisotropy, rate dependence, natural 'structure' or shear localisation.

\section{GEOTECHNICAL CONDITIONS}

The mean level of Lake Markermeer stands $\approx 1.1 \mathrm{~m}$ above that of the polder area; safety considerations rule out any testing of the dyke itself. Experiments were undertaken instead in the $80 \mathrm{~m}$ by $200 \mathrm{~m}$ polder area indicated in Fig. 2, whose elevation is $1.4 \mathrm{~m}$ below the NAP datum (reference datum corresponding to approximately mean sea level). The geotechnical profile was established from 18 boreholes and other borings sampled by Begemann (1971). Three typical $\operatorname{logs}$ are presented in Fig. 3, showing relatively uniform $\approx 5 \mathrm{~m}$ thick peat layers (units $\mathrm{o}, \mathrm{r}$ and $\mathrm{s}$ in Fig. 3) which have compressed by $\approx 80 \%$ under the dyke centre-line through centuries of consolidation and creep. The $\mathrm{H} 2$ to $\mathrm{H} 3$ Von Post category (Landva, 2007) peats comprise mainly Phragmites (with sedge and sphagnum inclusions) with minor vegetal decomposition. Water can be squeezed from the peat by hand, indicating relatively high permeability under low effective stresses. In situ falling head piezometer tests indicate 'free-field' permeabilities of $8.5 \times 10^{-7}$ to $2.3 \times 10^{-6} \mathrm{~m} / \mathrm{s}$. Organic and inorganic clays (layers $\mathrm{mc}$ and sc in Fig. 3) extend below the peat to approximately NAP $-10 \mathrm{~m}(8.8 \mathrm{~m}$ below ground level), beneath which a thin basal peat (bp) layer and thick Pleistocene aeolian sand (as) are present.

The near-surface groundwater is held $\approx 0.2 \mathrm{~m}$ below ground level by pumped ditches. Piezometric levels are $0.5 \mathrm{~m}$ lower in the underlying sand, but pore pressures are near-hydrostatic in the peat. As shown in Fig. 4, the peats' 


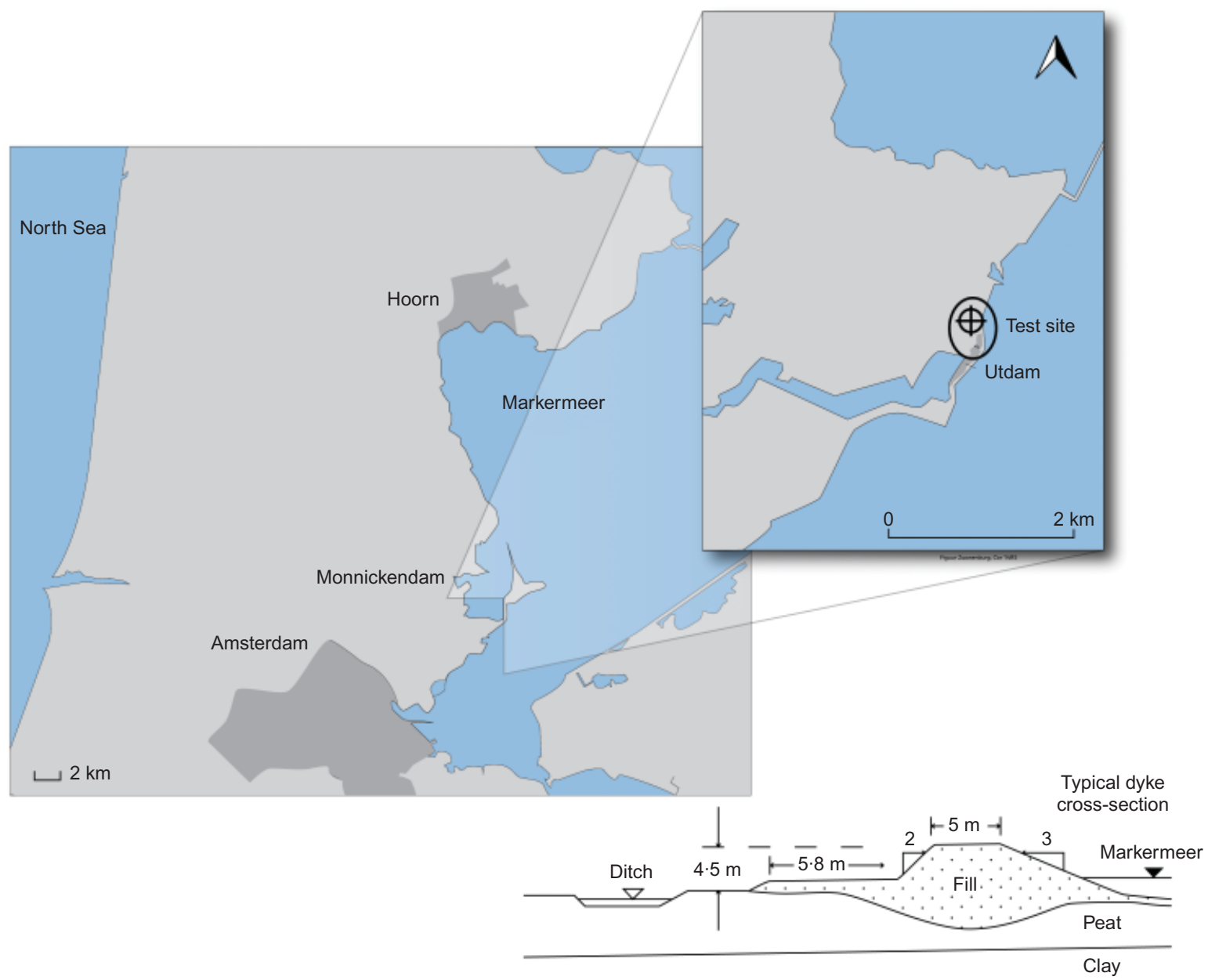

Fig. 1. Test site location

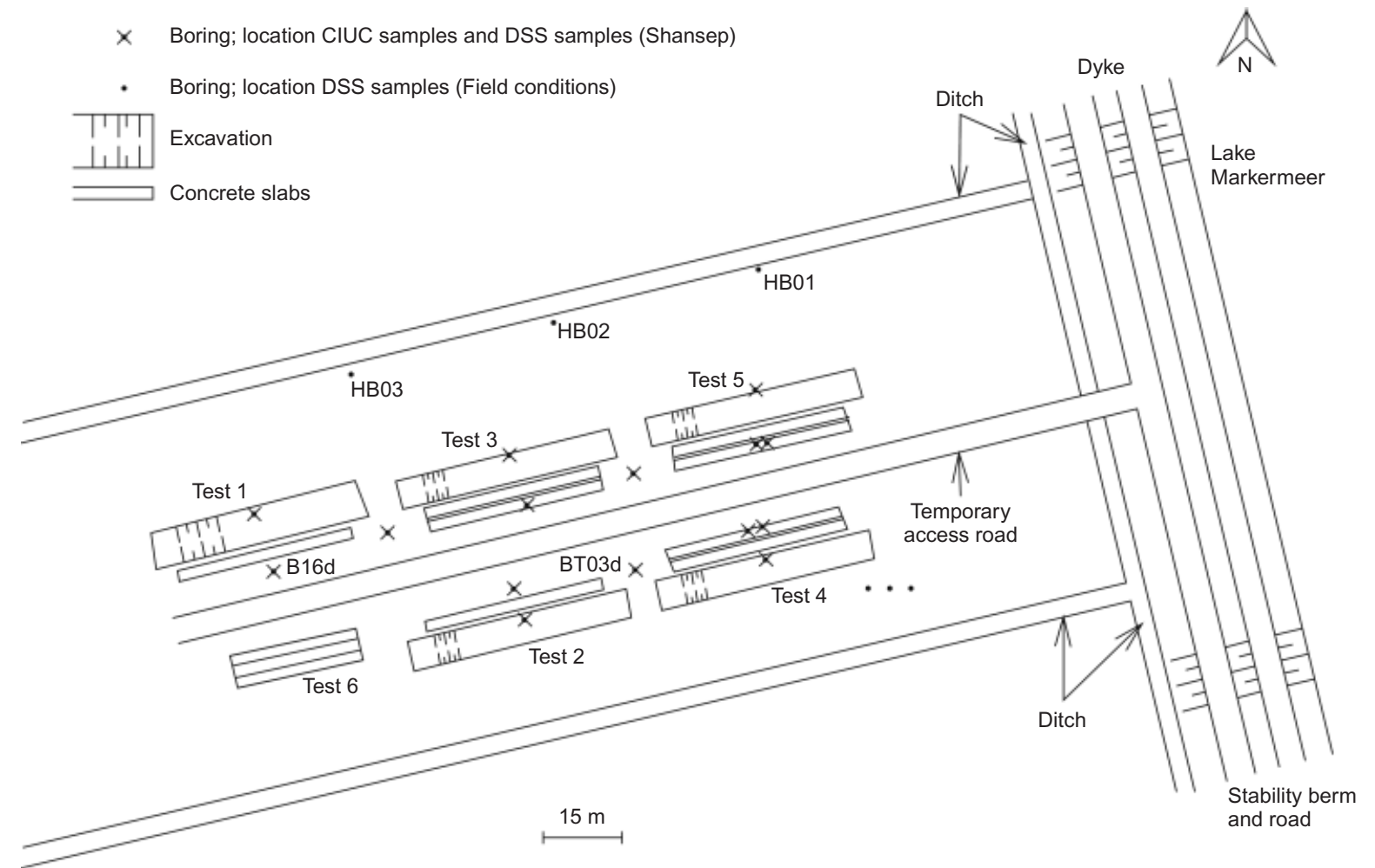

Fig. 2. Test site overview, the test results for the CIUC tests are given by Fig. 16, DSS (Shansep) refers to Fig. 17 and DSS (field conditions) refers to Fig. 18 


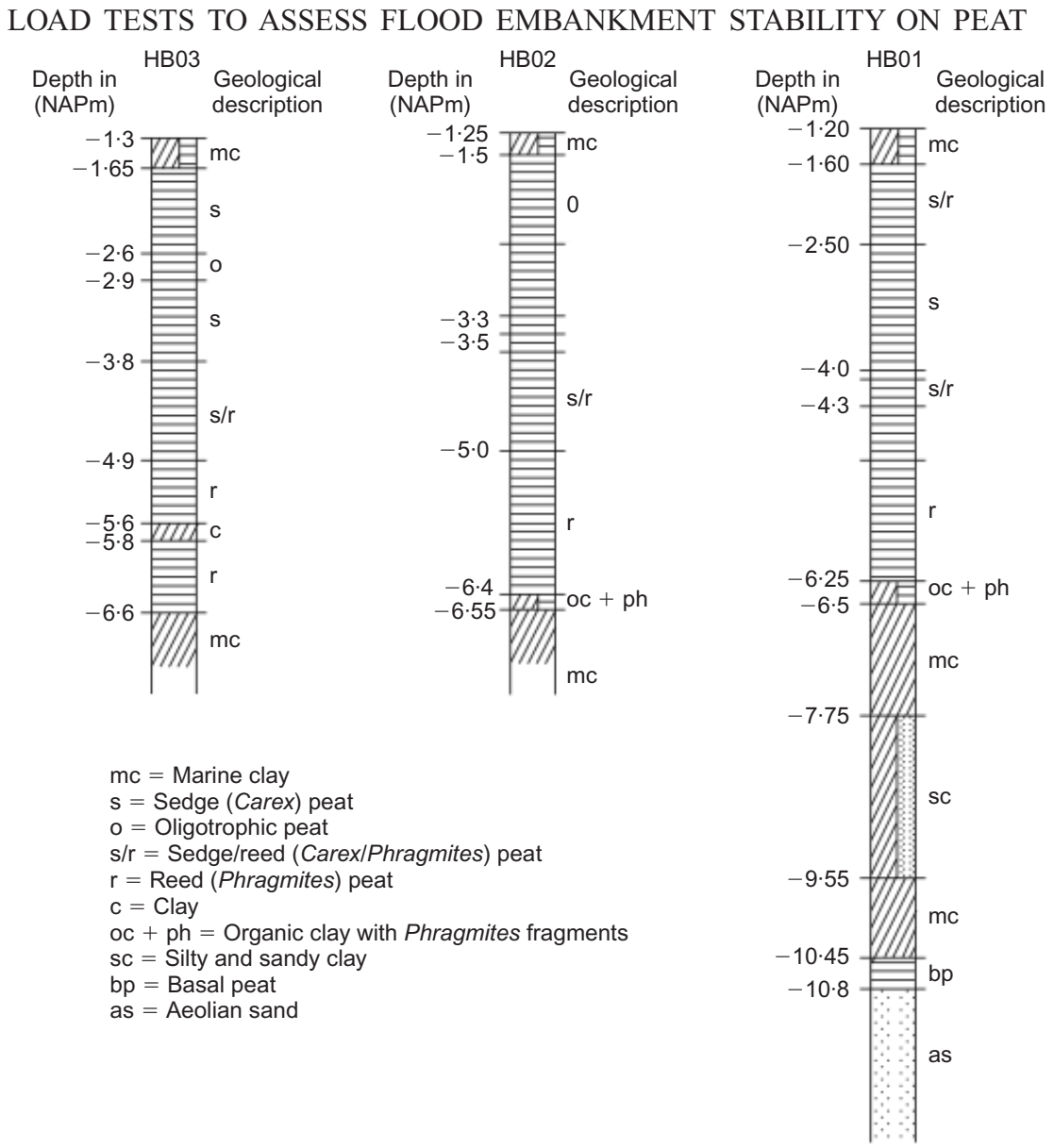

Fig. 3. Example borehole logs

laboratory bulk densities vary by $\pm 7 \%$ around $0.95 \mathrm{Mg} / \mathrm{m}^{3}$, falling below that of water due to the presence of gas; see Den Haan \& Kruse (2006) and Zwanenburg et al. (2012). While marginally higher densities might apply in situ, the vertical effective stress gradients with depth are likely to fall below $0.5 \mathrm{kPa} / \mathrm{m}$. The density of the peat solids is $1.53 \pm 1.6 \% \mathrm{Mg} / \mathrm{m}^{3}$, rising to $2.56 \pm 3 \% \mathrm{Mg} / \mathrm{m}^{3}$ in the underlying clay. Losses on ignition $(N)$ between $75 \%$ and $92 \%$ confirm the peat's organic content. Initial water contents fall between 645 and $1240 \%$ in the peat and are $\approx 75 \%$ in the underlying clay.

Laboratory shear strength testing and multiple piezocone $(\mathrm{CPTu})$, ball penetrometer and vane shear soundings indicate a range of initial undrained shear strengths $s_{\mathrm{u}}$ falling in the 4-20 $\mathrm{kPa}$ range, depending on the device applied and interpretation approach. However, the profiles given by each technique are generally uniform with depth below a thin surface 'crust'. Twenty-four hour staged loading oedometer tests conducted at $0.5 \mathrm{~m}$ depth intervals on samples from boreholes B16d and BT03d led to the void ratio $(e)-\log \sigma_{\mathrm{v}}^{\prime}$ plots in Fig. 4(d), showing normally consolidated $C_{\mathrm{c}}$ values of 2.5 to $4 \cdot 0$. The creep coefficients scale with compressibility, giving $C_{\alpha \mathrm{e}} / C_{\mathrm{c}} \approx 0 \cdot 08$. Vertical yield stresses $\sigma_{\mathrm{vy}}^{\prime}$ found applying the Becker et al. (1987) procedure confirm a thin crust and show $5<\sigma_{\mathrm{vy}}^{\prime}<14 \mathrm{kPa}$ in the main peat section (Fig. 4(e)), far exceeding the in situ $\sigma_{\mathrm{v} 0}^{\prime}$ profile, probably reflecting ageing and historical groundwater cycles. Oedometer coefficients of consolidation $c_{\mathrm{V}}$ fall between 0.06 and $2.3 \mathrm{~m}^{2} /$ year under normally consolidated conditions. However, combining the laboratory compressibility and in situ permeability measurements indicates far higher values (100 to $300 \mathrm{~m}^{2} /$ year) that correlate better with sample descriptions and, as described later, field behaviour. The underlying clays manifest higher $\sigma_{\mathrm{vy}}^{\prime}(15-24 \mathrm{kPa})$ and lower compressibilities, with $C_{\mathrm{c}}=0.4$ and 2.3 for the silty and organic clays, respectively, at over-consolidation ratio, $\mathrm{OCR}=1$. The oedometer $c_{\mathrm{v}}$ values range between 0.7 to $4.0 \mathrm{~m}^{2} /$ year in the silty clay and are lower in the organic clay.

\section{FIELD LOADING TESTS}

Five successful loading tests were conducted to failure, applying the arrangements shown in Figs 5 and 6, which were designed to $(a)$ match aspects of the dyke's sloping geometry and $(b)$ check the effects of consolidation under prolonged pre-loading. Vehicle traffic was restricted to a system of reinforced access roads to eliminate surface disturbance. Precast slabs, $2 \mathrm{~m}$ by $2 \mathrm{~m}$ in plan and $140 \mathrm{~mm}$ thick, were placed in $8 \mathrm{~m}$ by $2 \mathrm{~m}$ sets to provide total loading 'lengths' of up to $33.5 \mathrm{~m}$. Unlike earth fill, slabs can be weighed, lifted and re-used easily. They also eliminate uncertainty over fill properties and promote betterdefined collapse mechanisms; Jardine et al. (1997). The foundations were deemed to have failed when either the maximum settlement or horizontal displacement grew by $10 \%$ or more of the slab width $B$ within $10 \mathrm{~h}$. Table 1 details how such failures were induced by

(a) excavating, in tests 1 to 5 , slopes of similar lengths to the loading areas

(b) pumping water from the excavations

(c) stacking lines of concrete deadweight slabs

(d) increasing slab loading by filling the water tanks.

Table 2 summarises the instrumentation schemes. Water levels inside the containers and excavations were measured remotely, as were excavation heaves and container tilting 


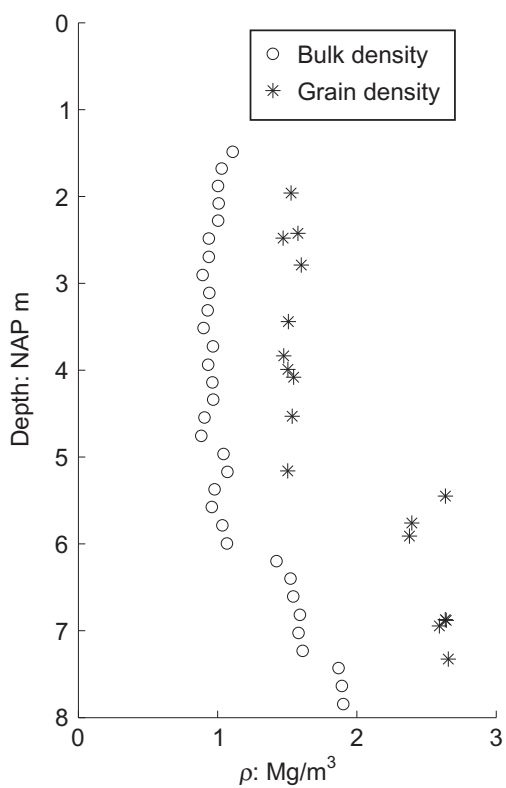

(a)

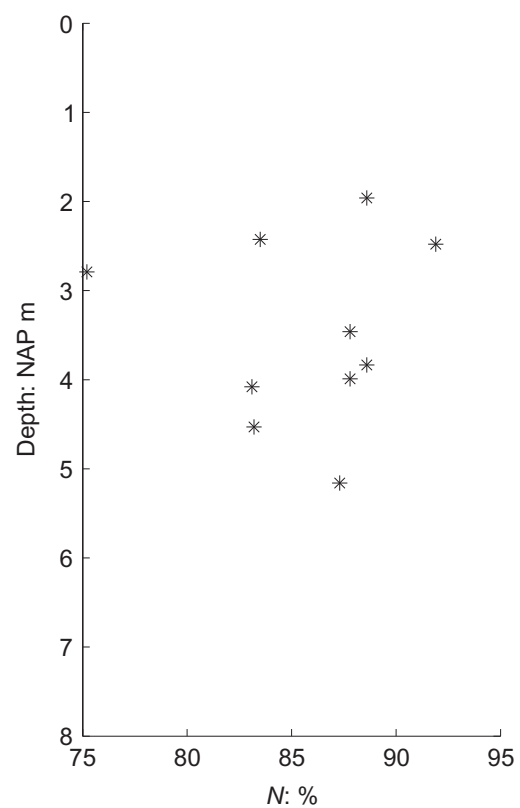

(b)

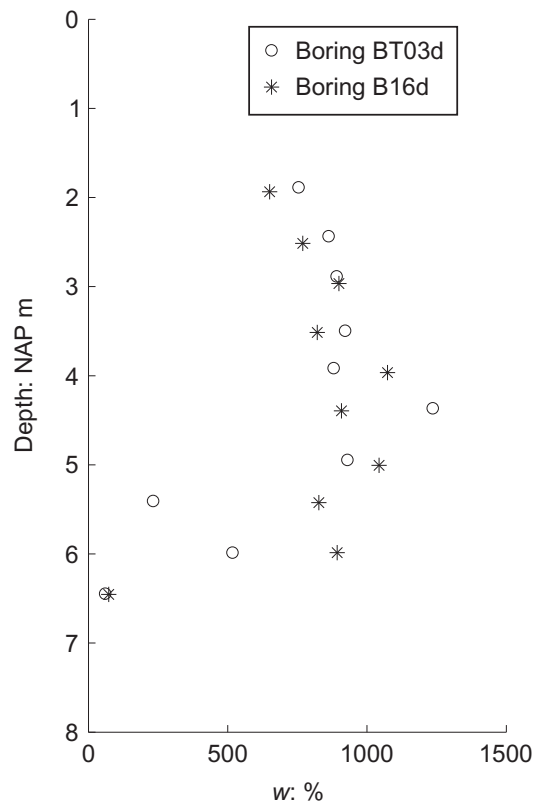

(c)

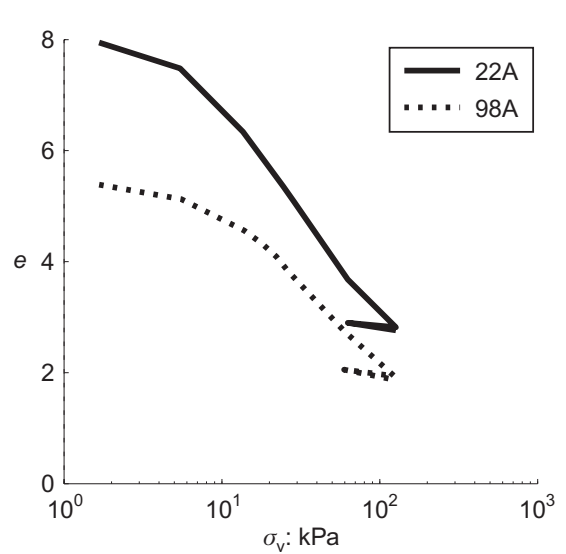

(d)

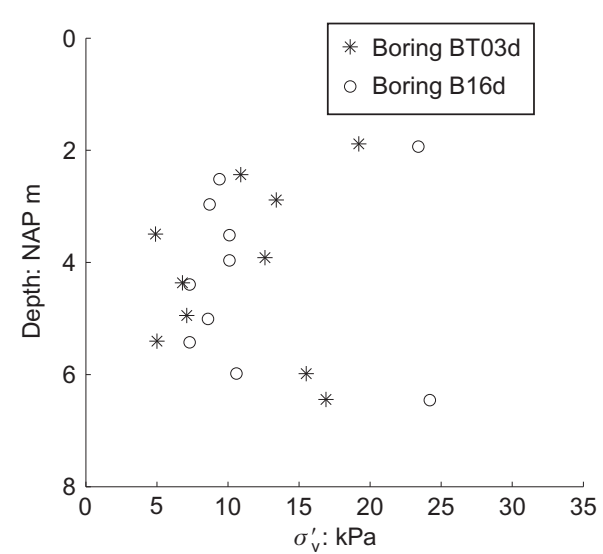

(e)

Fig. 4. Geotechnical profiles in peat: (a) bulk and grain densities, $\rho$; (b) losses on ignition, $N$; (c) water content, w; (d) typical oedometer tests; (e) vertical yield stresses, $\sigma_{\mathrm{vy}}^{\prime}$, from Becker et al. (1987) procedure

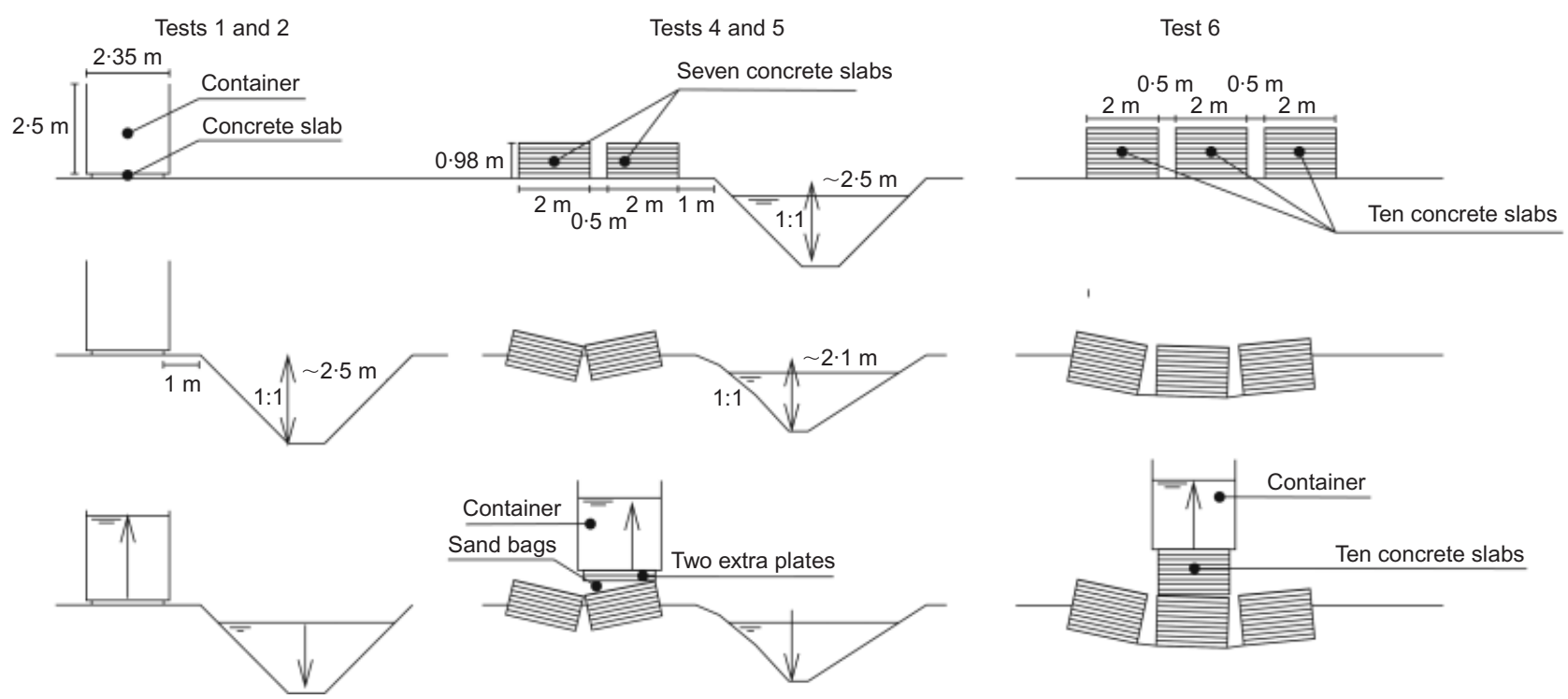

Fig. 5. Cross-section for each test type: all slab rows $0.5 \mathrm{~m}$ apart horizontally 


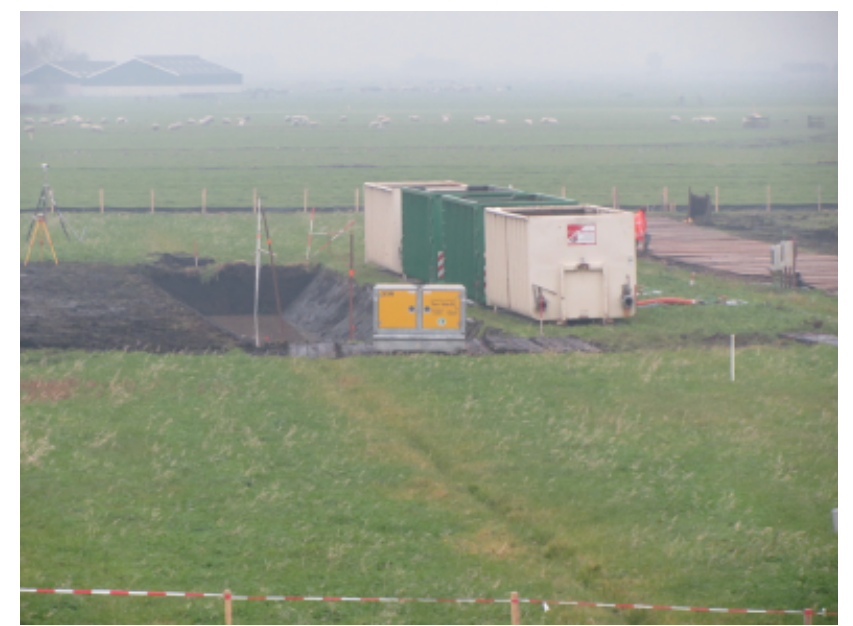

(a)

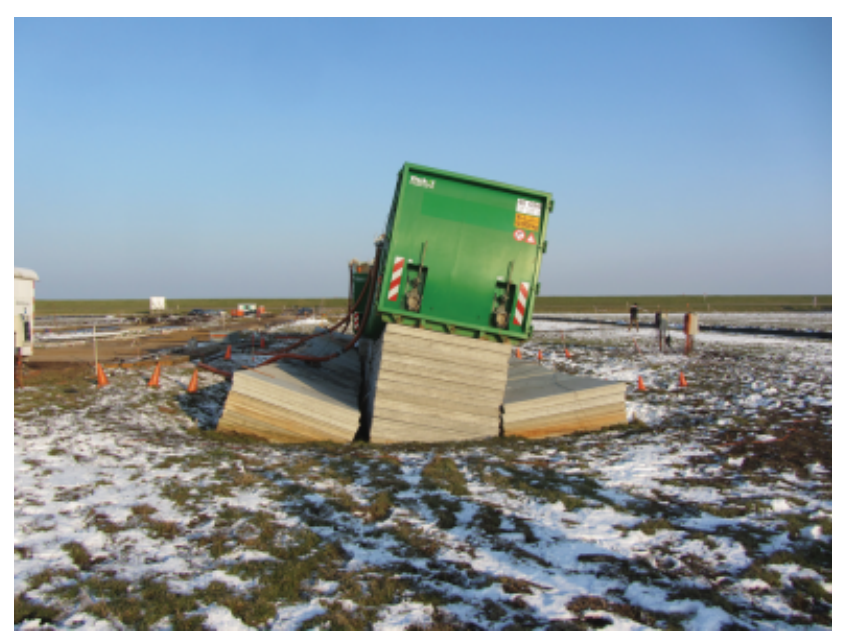

(b)

Fig. 6. Field photographs: (a) test 2 set-up; (b) test 6 post-failure. See Figs 2 and 5 for dimensions

over the final stages of tests 4, 5 and 6. Multiple vibrating wire piezometers were placed under the loading areas, while tube-way inclinometers were deployed at the edges of the loading slabs and surface settlement gauges at their centres. Trenches were cut after testing to identify shear surfaces. In situ probing was also conducted in stages to assess possible soil property changes.

The first two tests involved single lines of slabs, whereas twin lines were incorporated into tests 4 and 5 to extend the loaded area and push the failure to greater depth. Tests 1 and 2 were rapid and test 3 was not completed successfully. Test 4 included an initial 3-week pre-loading period before a second 11-week loading pause and its final rapid failure stage. Test 5 involved a similar sequence with a 5 -week first pause and a 9-week second 'consolidation' stage before inducing shear failure.

Test 6 focused principally on the effects of pre-loading and had the most intensive instrumentation scheme, as outlined in Fig. 7. It adopted three lines of slabs and extended over 215 days. Some settlement data were lost from container areas 2 and 3, owing to a logging malfunction. However, surveying checks confirmed the container 1 data as being broadly representative. Eliminating the excavation allowed higher loading levels to be imposed. While consolidation progressed to achieve almost full equilibrium over 10 days under the first load step, around 3 months were required for full dissipation under the final stage of pre-loading.

Tests 1 and 2, which involved loading single lines of $2 \mathrm{~m}$ wide slabs, were completed within 3 days of excavation starting and their rapid loading stages led to 'single-stage' (after Jardine, 2002) failures in which stability was controlled by the peats' initial shear strength profile. While pore pressures were free to dissipate, settlements remained relatively modest until rapid failure was induced: see Figs 810. In situ probing tests conducted before and after testing confirmed that no significant $s_{\mathrm{u}}$ gains developed beneath tests 1 and 2 . However, the peats' $s_{\mathrm{u}}$ distributions evolved more significantly over the extended 'multi-stage' tests with bearing capacity improving through consolidation and creep under those areas where settlements were large and the effective stress gains more significant.

\section{TEST OUTCOMES}

The tests' final failure patterns are illustrated in Fig. 8, drawing from instrument records, field observations, photographs and post-failure trenches. Figs 9 and 10 present the maximum settlements and horizontal movements measured, covering the full loading periods of tests 1 and 2 and the last 48 to $76 \mathrm{~h}$ of the multi-stage tests 4,5 and 6 . Arrows identify the failure periods, with durations ranging from less than 10 min (tests 1 and 6) to almost $10 \mathrm{~h}$ in test 5. Fig. 11 outlines the piezometer and settlement records near failure from the clear 'single-stage' tests 1 and 2, which first induced failure by excavation followed by vertical slab loading (of 23 to $25 \mathrm{kPa}$ ) and finally ditch lowering. Pore pressures rose just 2 to $5 \mathrm{kPa}$ above the hydrostatic $(-1.6 \mathrm{~m}$ NAP) profile over the first $50 \mathrm{~h}$ of test 1 . Marked changes of both signs were seen during the final ditch lowering period, with surface settlement growing by $\approx 0.5 \mathrm{~m}$ in $10 \mathrm{~min}$. Test 2 carried slightly less surface loading and was therefore able to sustain an additional $\approx 0.5 \mathrm{~m}$ of excavation water lowering before failure, with settlements growing by $0.3 \mathrm{~m}$ over $250 \mathrm{~min}$. The test 2 piezometers showed similarly small excess pressures $(<6 \mathrm{kPa})$ prior to failure, responding negatively to excavation pumping and rising gently during the eventual failure. The inclinometers indicated sudden horizontal movements of 0.5 to $0.6 \mathrm{~m}$ as failure developed in test 1 , with the central instrument finally becoming unreadable. More gradual increases in horizontal displacements were noted in test 2.

The extended pre-loading stages of test 6 provide the clearest evidence of the field consolidation behaviour. As shown in Fig. 12, $1.5 \mathrm{~m}$ of surface settlement developed over the first 215 days under the regime outlined in Table 1, generating $\approx 35 \%$ centre-line vertical strain in the peat. Each of the four surface loading steps applied led to 4$7 \mathrm{kPa}$ pore pressure rises that decayed over equalisation times that grew with load from $\approx 10$ days to $\approx 3$ months. The Appendix presents numerical back-analyses that show global peat $c_{\mathrm{V}}$ values declining from $\approx 5000 \mathrm{~m}^{2} /$ year under low loading levels in test 5 to $\approx 180 \mathrm{~m}^{2} /$ year in the final loading stages of test 6 , with best matching permeabilities falling in the range found from in situ falling head tests. Pumping water from the deep settlement trough formed around test 6 (see Fig. 8) led to marked pore pressure reductions, as well as further settlements that gradually slowed over the following 60 days.

The final failure of test 6 was induced between days 216 and 218 by adding ten extra concrete slabs and $\approx 1 \mathrm{~m}$ of water in the three tanks. As shown in Fig. 13, the settlement and lateral movement maxima grew by $\approx 0.4 \mathrm{~m}$ and $\approx 0.25 \mathrm{~m}$ over $5 \mathrm{~min}$. The multi-stage loading case experienced the most rapid final failure, as suggested by Jardine et al. (1997) and Jardine (2002). Pore pressures fell rapidly in the two deepest piezometers before rising to $\approx 10 \mathrm{kPa}$ above their day 217 levels, while the two shallower instruments 
Table 1. Main steps applied at specified dates in tests 1, 2, 4, 5 and 6

\begin{tabular}{|c|c|c|c|c|c|}
\hline Load & Test 1 & Test 2 & Test 4 & Test 5 & Test 6 \\
\hline \multicolumn{6}{|l|}{ Ditch excavation } \\
\hline Start & 20 October 2011 & 27 October 2011 & 22 November 2011 & 24 November 2011 & - \\
\hline Depth of cut ditch ${ }^{*}$ & $\begin{array}{l}3 \cdot 0 \mathrm{~m}^{\dagger}, 2 \cdot 0 \mathrm{~m}^{\dagger} \text { at } \\
\text { failure }\end{array}$ & $\begin{array}{l}2.5 \mathrm{~m}, 2.1 \mathrm{~m} \text { at failure, } \\
1.7 \mathrm{~m} \text { after failure }\end{array}$ & $\begin{array}{l}2.5 \mathrm{~m} \text { rising to } 2.1 \mathrm{~m} \\
\text { after consolidation } \\
\text { period and } 1.4-1.8 \mathrm{~m} \\
\text { after failure }\end{array}$ & $\begin{array}{l}2.5 \mathrm{~m} \text { rising to } 2.4 \mathrm{~m} \\
\text { after consolidation } \\
\text { period and } 1 \cdot 8-2 \cdot 1 \mathrm{~m} \\
\text { after failure }\end{array}$ & None \\
\hline Slope & $1: 1$ & $1: 1$ & $1: 1$ & $1: 1$ & - \\
\hline Base width & $1 \mathrm{~m}$ & $1 \mathrm{~m}$ & $0.5 \mathrm{~m}$ & $0.5 \mathrm{~m}$ & \\
\hline Water level in cut ditch & $\begin{array}{l}-1.9 \mathrm{~m} \mathrm{NAP} \\
-2 \cdot 2 \mathrm{~m} \mathrm{NAP} \text { at } \\
\text { failure }\end{array}$ & $\begin{array}{l}-2 \cdot 2 \mathrm{~m} \text { NAP } \\
\text { Empty at failure }\end{array}$ & $\begin{array}{l}-1 \cdot 6 \mathrm{~m} \text { NAP to } \\
-1 \cdot 8 \mathrm{~m} \text { NAP } \\
\text { Empty* at failure }\end{array}$ & $\begin{array}{l}-1 \cdot 2 \mathrm{~m} \mathrm{NAP} \text { to } \\
-1.5 \mathrm{~m} \text { NAP } \\
-2 \mathrm{~m}^{\ddagger} \mathrm{NAP} \text { at failure }\end{array}$ & \\
\hline Time** & 0 to $12 \cdot 43 \mathrm{~h}$ & 0 to $17 \cdot 75 \mathrm{~h}$ & 0 to $27 \cdot 00 \mathrm{~h}$ & 0 to $26 \cdot 50 \mathrm{~h}$ & \\
\hline
\end{tabular}

Surface (pre-)loading

\begin{tabular}{|c|c|c|c|c|c|}
\hline $\begin{array}{l}\text { Start } \\
\text { Days } \\
\text { Load } \\
\text { Date } \\
\text { Days } \\
\text { Load } \\
\text { Date } \\
\text { Days } \\
\text { Load } \\
\text { Date } \\
\text { Days } \\
\text { Load }\end{array}$ & - & $\begin{array}{l}\text { No preload } \\
-\end{array}$ & $\begin{array}{l}5 \text { December } 2011 \\
19 \cdot 5 \\
13 \cdot 4 \mathrm{kPa} \\
13 \mathrm{December} 2011 \\
27 \cdot 5 \\
20 \cdot 1 \mathrm{kPa} \\
27 \mathrm{December} 2011 \\
41 \cdot 5 \\
23 \cdot 5 \mathrm{kPa}\end{array}$ & $\begin{array}{l}12 \text { December } 2011 \\
17 \cdot 5 \\
13 \cdot 4 \mathrm{kPa} \\
19 \mathrm{December} 2011 \\
24 \cdot 5 \\
20 \cdot 1 \mathrm{kPa} \\
16 \mathrm{January} 2012 \\
52 \cdot 5 \\
23 \cdot 5 \mathrm{kPa}\end{array}$ & $\begin{array}{l}10 \text { July } 2012 \\
0 \\
13 \cdot 4 \mathrm{kPa} \\
24 \text { July } 2012 \\
14 \\
20 \cdot 1 \mathrm{kPa} \\
7 \text { August } 2012 \\
28 \\
26 \cdot 5 \mathrm{kPa} \\
4 \mathrm{September} 2012 \\
56 \\
33 \cdot 6 \mathrm{kPa}\end{array}$ \\
\hline
\end{tabular}

Action to induce failure

\begin{tabular}{|c|c|c|c|c|c|}
\hline Extra load & $6.6 \mathrm{kPa}^{\mathbb{\imath}}$ & $6.6 \mathrm{kPa}^{\top}$ & $12 \cdot 5 \mathrm{kPa}^{\llbracket}$ & $10 \cdot 7 \mathrm{kPa}$ & $35 \cdot 2 \mathrm{kPa}$ \\
\hline Water tank & $1.9 \mathrm{~m}$ & $1 \cdot 8 \mathrm{~m}$ & $0.5 \mathrm{~m}$ & $0 \cdot 8 \mathrm{~m}$ & $1 \cdot 0 \mathrm{~m}$ \\
\hline Load & $18 \cdot 4 \mathrm{kPa}$ & $17 \cdot 2 \mathrm{kPa}$ & $\begin{array}{l}4 \cdot 9 \mathrm{kPa} \\
\text { (with } 2 \cdot 3 \mathrm{~m} 22 \cdot 1 \mathrm{kPa} \\
\text { in container } 3 \text { ) }\end{array}$ & $7 \cdot 4 \mathrm{kPa}$ & $9 \cdot 8 \mathrm{kPa}$ \\
\hline Date & 20-22 October 2011 & 27-29 October 2011 & 12-15 March 2012 & 19-22 March 2012 & 11-12 February 2013 \\
\hline Total load & $25 \mathrm{kPa}$ & $23 \cdot 75$ & $\begin{array}{l}40 \cdot 9 \mathrm{kPa}(58 \cdot 1 \mathrm{kPa} \\
\text { under container } 3)\end{array}$ & $41 \cdot 5 \mathrm{kPa}$ & $78 \cdot 6 \mathrm{kPa}$ \\
\hline Corrected total load ${ }^{* *}$ & $\begin{array}{l}\text { No correction } \\
\text { required }\end{array}$ & $\begin{array}{l}\text { No correction } \\
\text { required }\end{array}$ & $\begin{array}{l}34 \cdot 38 \mathrm{kPa}(40 \cdot 2 \mathrm{kPa} \\
\text { under container } 3)^{* *}\end{array}$ & $31 \cdot 4 \mathrm{kPa}^{* *}$ & $71.9 \mathrm{kPa}^{\dagger \dagger}$ \\
\hline Time & $27 \cdot 18$ to $57 \cdot 05 \mathrm{~h}$ & $27 \cdot 07$ to $62 \cdot 70 \mathrm{~h}$ & $\begin{array}{l}2819 \cdot 3 \text { to } 2892 \cdot 8 \mathrm{~h} \\
(73 \cdot 47 \mathrm{~h})\end{array}$ & $\begin{array}{l}2974 \cdot 1 \text { to } 3042 \cdot 2 \mathrm{~h} \\
(68 \cdot 10 \mathrm{~h})\end{array}$ & $\begin{array}{l}5185 \cdot 4 \text { to } 5216 \cdot 1 \mathrm{~h} \\
(30 \cdot 62 \mathrm{~h})\end{array}$ \\
\hline
\end{tabular}

\footnotetext{
* Swelling and heave after excavation reduced the final depths.

$\dagger$ Uplift of test 1 during excavation made depth level uncertain.

\$ Water level was lowered in steps to this final level.

$\S$ Duration since start excavation (tests 4 and 5) or loading (test 6).

॥ Total load applied, not corrected for water uplift pressures.

" Additional load in tests 1 to 6 from extra concrete slabs and empty tank.

** Corrected for hydraulic uplift due to settlement below groundwater table.

i† Free water between plates was removed in test 6 leading to smaller correction.

$\$$ Time in hours since start of test, for tests 4,5 and 6 duration of loading phase in brackets.
}

rose monotonically to exceed their day 217 levels by 10 $15 \mathrm{kPa}$.

Tests 4 and 5 developed rotational mechanisms in which most slabs tilted by $\approx 20^{\circ}$, leading to water tanks sliding, spilling and toppling into their excavations. However, the test 4 container 3 failed by vertical settlement, simplifying the interpretation that follows.

\section{INTERPRETATION AIDED BY SIMPLE TRESCA FINITE- ELEMENT ANALYSIS}

The field tests all involved relatively rapid, principally undrained, final failures. One key practical engineering objective was to gauge the Tresca undrained shear strengths, $s_{\mathrm{u}}$, that best matched the field collapse conditions and could be applied in dyke stability assessments. Short-term failures under long rigid strips resting on deep horizontal layers of Tresca media can be treated by classical bearing capacity theory, where $N_{\mathrm{c}}$ factors relate surface failure load $q_{\mathrm{u}}$ to the shear strength $s_{\mathrm{u}}$

$$
N_{\mathrm{c}}=\frac{q_{\mathrm{u}}}{s_{\mathrm{u}}}
$$

Factors have been derived to allow for limited soil depths, foundation lengths and linear $s_{\mathrm{u}}$-depth profiles (Davis \& Booker, 1973). Rigid foundations placed near slopes can also be considered (Georgiadis, 2010). However, application to the Uitdam tests is hindered by 
Table 2. Instrumentation for all tests, except test 3 which failed prematurely and is not reported

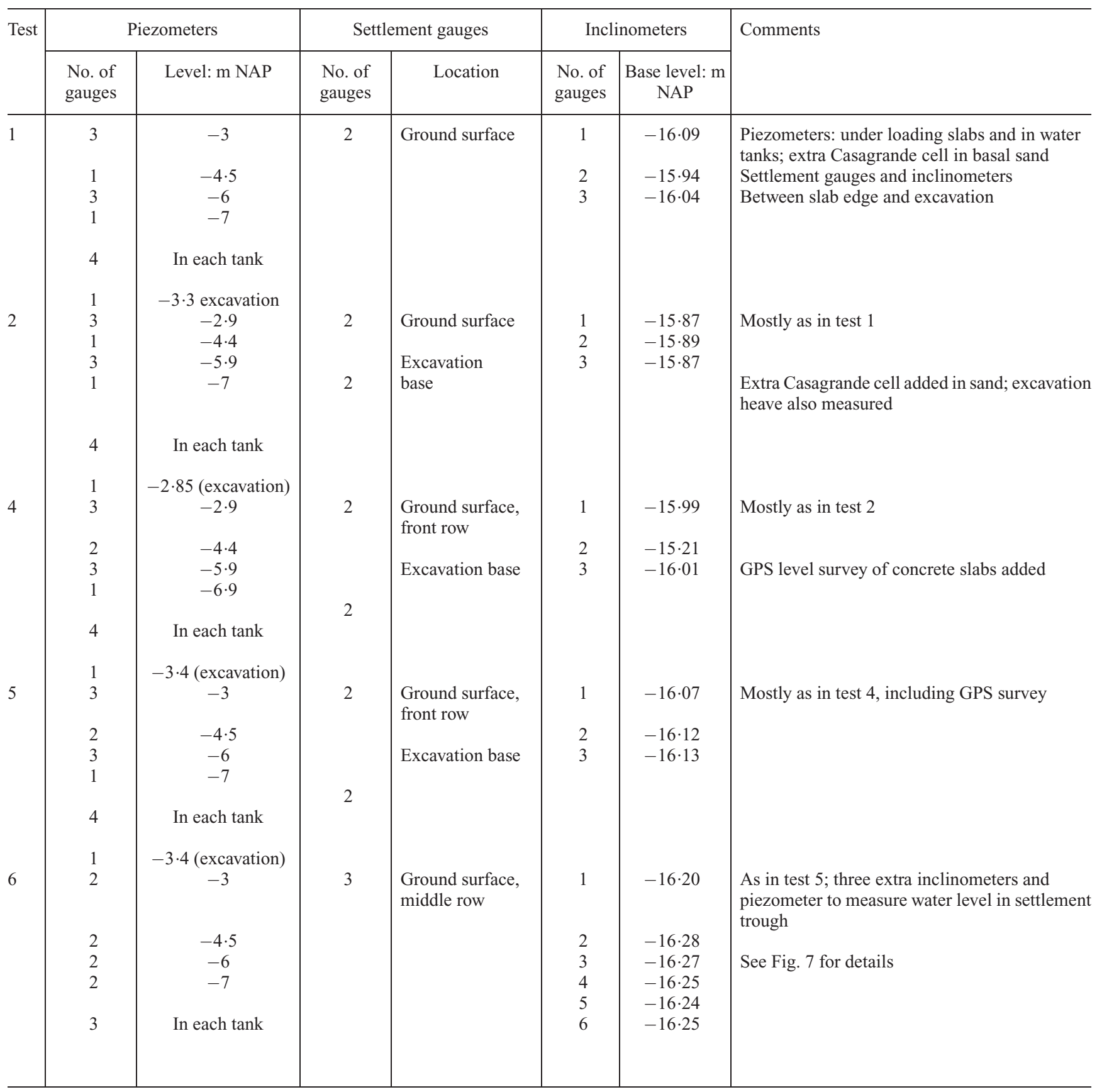

(a) the peat being bounded at moderate depth by marginally stronger clay

(b) complex geometry and significant ground pre-failure deformations

(c) external water forces applying significant (stabilising and disturbing) actions.

Plane strain, small-displacement, Plaxis (v. 2012.01) finite-element analyses were performed, mainly with simple elastic-Tresca models, to aid the practical interpretation reported here. The meshes comprised 15-noded triangular elements and loading was idealised as being evenly distributed onto weightless, nominally reinforced, structural concrete elements whose axial stiffness, $E A=4 \cdot 2 \times 10^{6} \mathrm{kN} / \mathrm{m}$ and flexural rigidity was $\mathrm{EI}=6860 \mathrm{kNm}^{2} / \mathrm{m}$, corresponding to a thickness, $d=0 \cdot 14 \mathrm{~m}$. The slab weights were included in the applied load and rigid, rough interface elements (with a virtual thickness of $0.1 \mathrm{~m}$ ) were specified beneath the slabs. The simple failure analyses accounted partially for the significant pre-failure deformations by incorporating the field settlement profiles (as measured just before failure) into the mesh geometry. They also allowed the loading arrangement and the free water levels observed in the ditches and any settlement troughs around the loaded area to be captured. Varying the mesh base boundary conditions between being rough or smooth affected the collapse loads by less than $1 \%$. Checks were also made against published solutions; $N_{\mathrm{c}}$ values of 3.39 and 3.26 were computed for tests 1 and 2 that agreed with extrapolations from Georgiadis (2010). Scope clearly exists for investigating three-dimensional geometry and large strain effects. More advanced constitutive modelling could also address: coupled consolidation; nonlinear permeability; shear strength anisotropy; rate dependency; and any significant aspects of the peats' natural structure.

Peat unit weights between $10 \cdot 1 \mathrm{kN} / \mathrm{m}^{3}$ and $10 \cdot 5 \mathrm{kN} / \mathrm{m}^{3}$ 

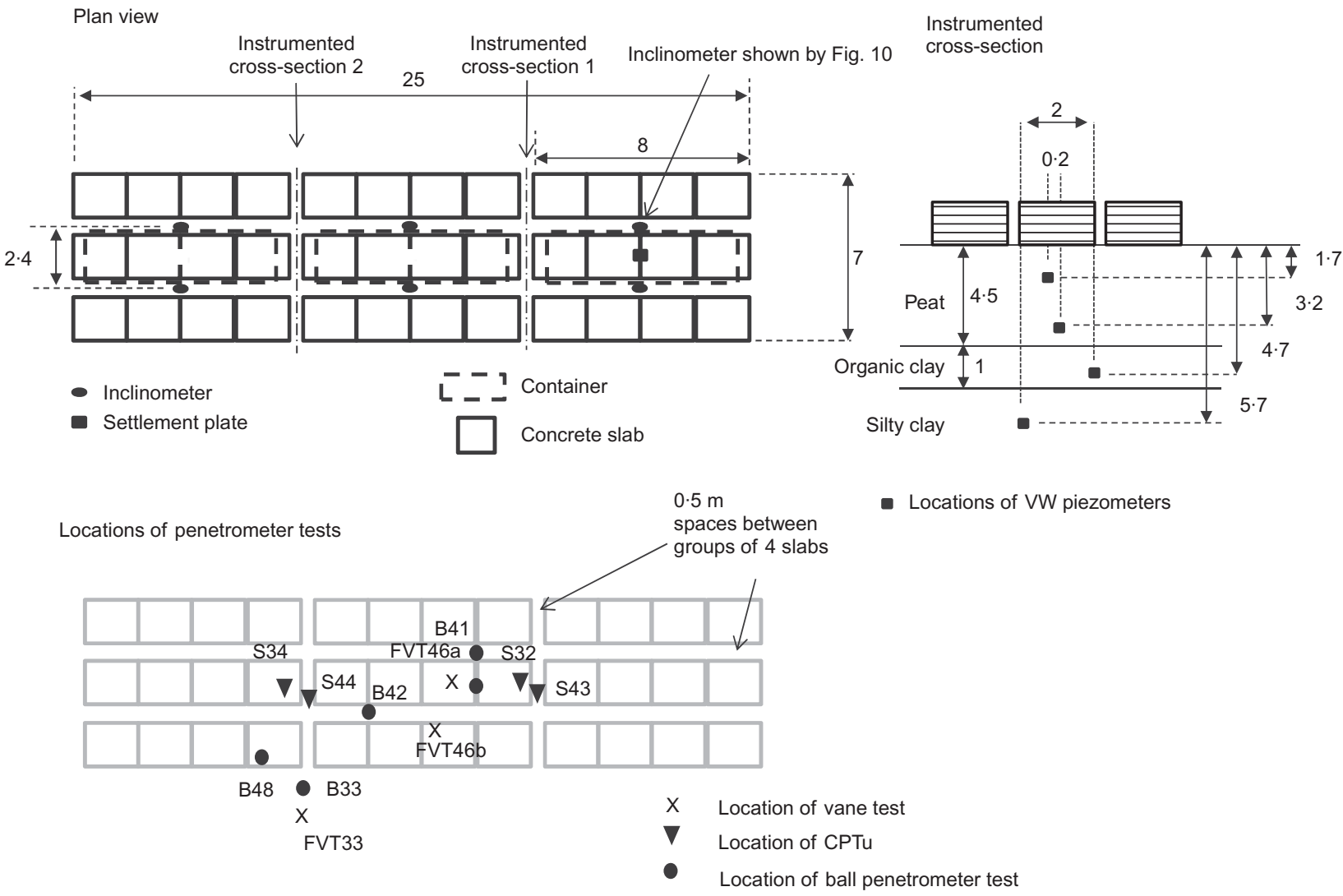

Fig. 7. Plan and section details of arrangements and instrumentation for test 6 (measurements in $\mathrm{m}$ )

were specified, depending on the degree of peat precompression. Linear undrained stiffnesses were gauged, from the mid-points of triaxial tests, as $E_{50 \text { undrained }}=500$ and $800 \mathrm{kPa}$, respectively, for the 'polder' and 'pre-compressed' areas. The basal organic clay layer was assumed to have an operational $s_{\mathrm{u}} \approx 8 \mathrm{kPa}$. The finite-element meshes were designed with the excavated slopes in place and accounted for the pre-failure settlement and water level profiles. The initial total stresses were assessed by assuming a low initial $K_{0}$ $(0.3)$ in the high $\phi^{\prime}$ peat and a phreatic surface set $0.2 \mathrm{~m}$ below ground level. Gravity was activated without attempting to model the ditch excavation process.

Tests 1 and 2 were analysed first to find average 'polder' $s_{\mathrm{u}}$ values assuming $(a)$ no significant variation with depth and $(b)$ the short loading durations did lead to any foundation improvement through consolidation. As shown later, both assumptions are supported by comprehensive in situ test profiling. Fig. 14 shows the typical finite-element mesh employed and Table 3 lists the $7 \cdot 3<s_{\mathrm{u}}<7.4 \mathrm{kPa}$ range back-analysed from the two collapses. 'Bishop and Spencer' limit equilibrium calculations gave similar results: $7 \cdot 0<s_{\mathrm{u}}<7.8 \mathrm{kPa}$. Fig. 15 illustrates the predicted failure mechanisms, which correspond reasonably well to the field outcomes: see Fig 8. Similar assessments were made for tests 4, 5 and 6, giving the results presented in Table 3. Noting the difficulty of imposing the field tilting and sliding conditions, the test 4 analyses adopted the movements and conditions applying under the 'vertically settling' container 3. A similar approach was applied for test 5 and it is recognised that these two back-analyses could be less representative than those for tests 1,2 and 6 . The equivalent uniform $s_{\mathrm{u}}$ values from the multistage tests range between 8.5 and $13.2 \mathrm{kPa}$. While all exceed the test 1 and 2 average of $7.3 \mathrm{kPa}$, the relationship between computed $s_{\mathrm{u}}$ and degree of preloading is not systematic, suggesting that the initial 'polder' shear strength profiles vary spatially. This conclusion is supported by the laboratory and field shear strength measurements considered below.

\section{LABORATORY SHEAR STRENGTH CHARACTERISATION}

The laboratory shear testing on Begemann samples encompassed direct simple shear (DSS) tests and isotropically consolidated undrained compression (CIUC) triaxial tests. $K_{0}$ is hard to estimate reliably with peats and anisotropic reconsolidation is difficult to apply at very low effective stresses. Twenty-two normally consolidated CIUC tests were sheared to failure at $0.75 \%$ axial strain $/ \mathrm{h}$, as outlined in Table 4 and Fig. 16. The effective stress paths all showed $p^{\prime}$ reductions (and pore pressures rises), with high mobilised $M$ (and hence $\phi^{\prime}$ ) values as they approached $\sigma_{\mathrm{r}}^{\prime}=0$ tension cut-off (TCO) limit of the apparatus. Relatively few of the deviator stress $(q)$-axial strain traces shown in Fig. 16(b) developed peaks before the equipment strain limits were reached. The results mirror the findings of Yamaguchi et al. (1985), Den Haan \& Kruse (2006) and Zwanenburg et al. (2012). Den Haan \& Kruse (2006) noted that $K_{0}$ reconsolidated samples develop smaller strains and pore pressure up to their TCO limits and suggested that cracks form in the field on $\sigma_{3}^{\prime}=0$ planes. They proposed the projection sketched in Fig. 16 to estimate field 'triaxial shear strengths'. Applying this and correlating with consolidation stresses leads to $s_{\mathrm{u}} / \sigma_{1 \mathrm{c}}^{\prime}=0.59( \pm 22 \%)$, which falls within the ranges reported by Den Haan \& Kruse (2006), Mesri \& Ajlouni (2007) and Zwanenburg et al. (2012). In the absence of a systematic study of the effects of over-consolidation, $s_{\mathrm{U}}-$ OCR relationships can be estimated (after Ladd \& Foot, 1974) from oedometer compression (CR) and recompression (RR) ratios as 

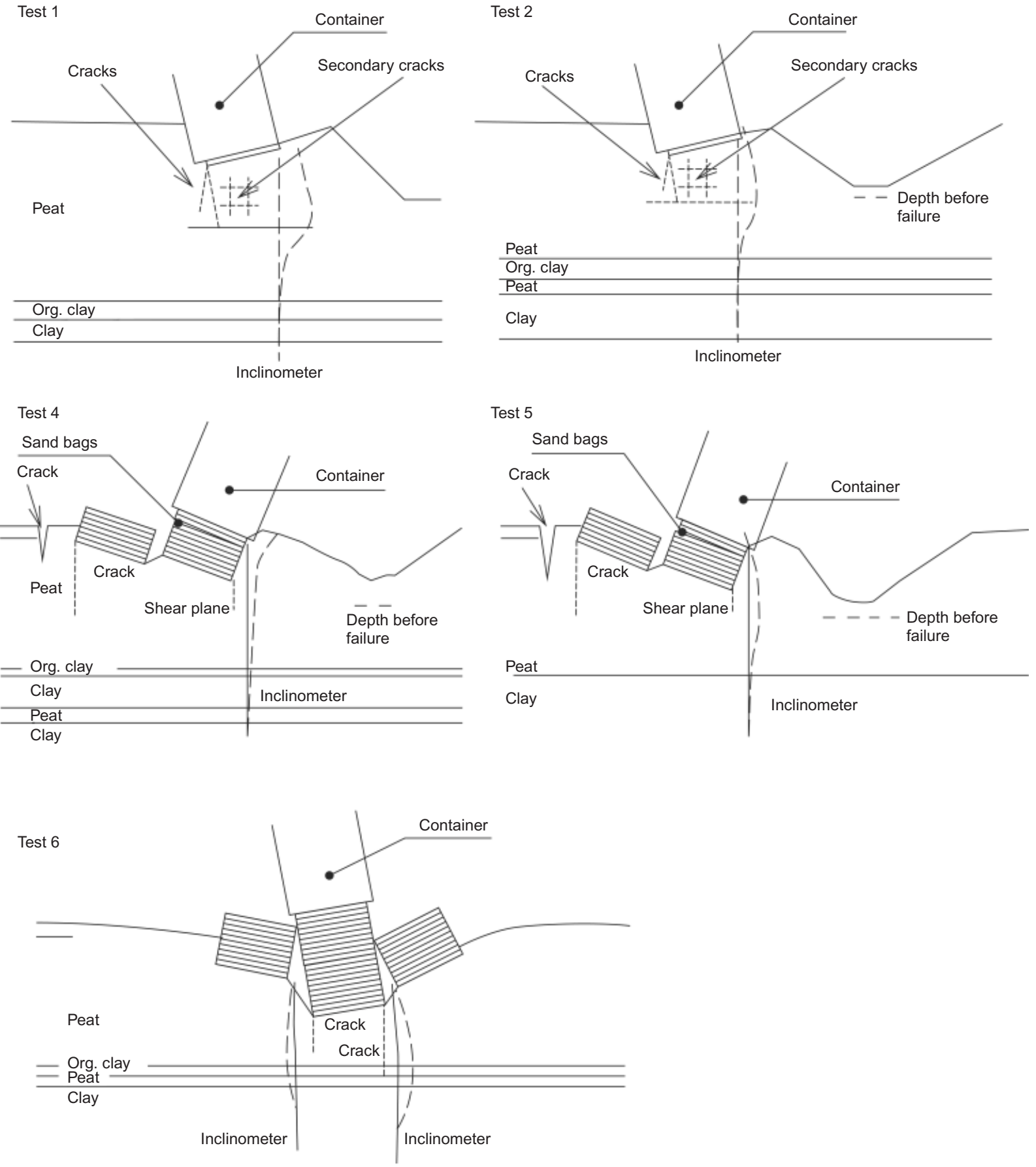

Fig. 8. Failure mechanisms in each test: to scale with no vertical exaggeration

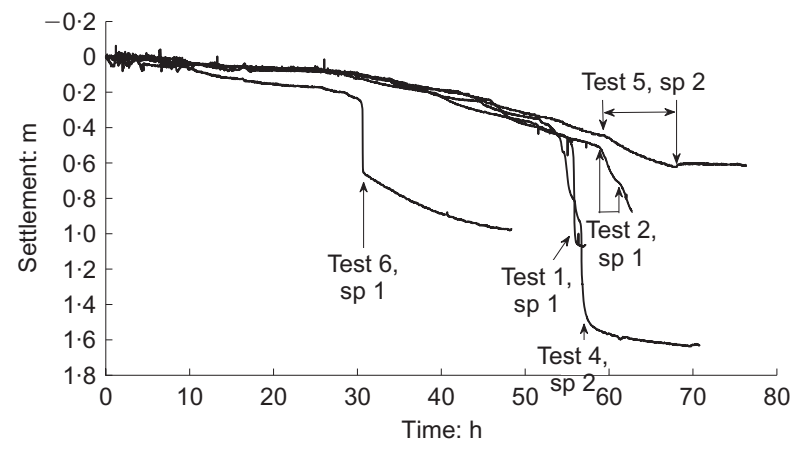

Fig. 9. Settlement during loading phase, arrows indicate failure. Time origin is the start of first excavation, tests 1 and 2, or final surface loading stage in tests 4,5 and 6 (note $s p=$ settlement plate)

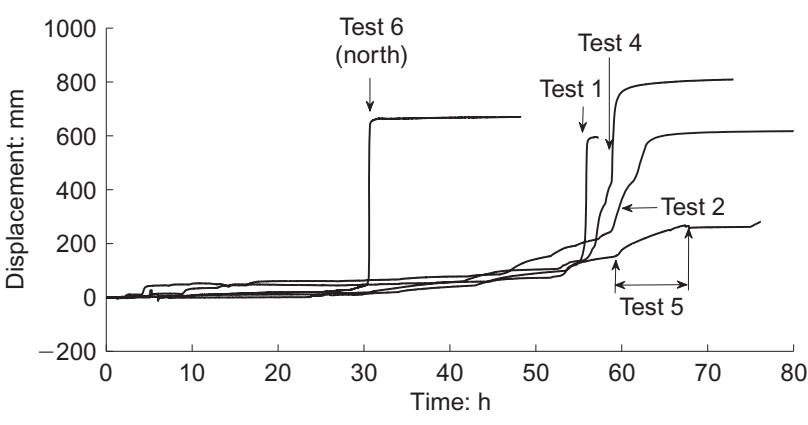

Fig. 10. Maximum horizontal sub-soil displacement during loading phase, arrows indicate failure. Time origin is the start of first excavation, test 1 and 2 , or final surface loading stage in tests 4,5 and 6 

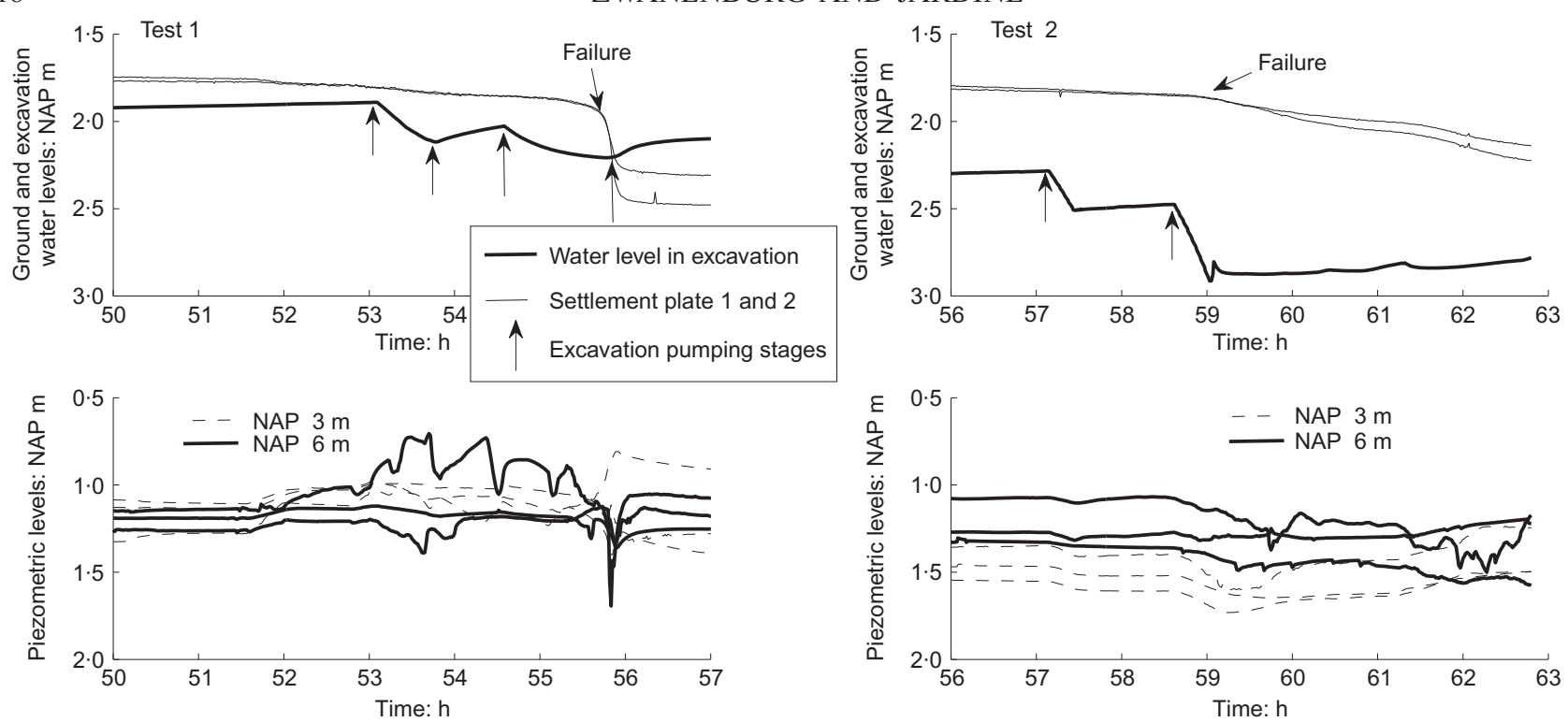

Fig. 11. Settlement and piezometer measurements over final failure stages of test 1 and 2. Time origin is the start of first excavation or surface loading

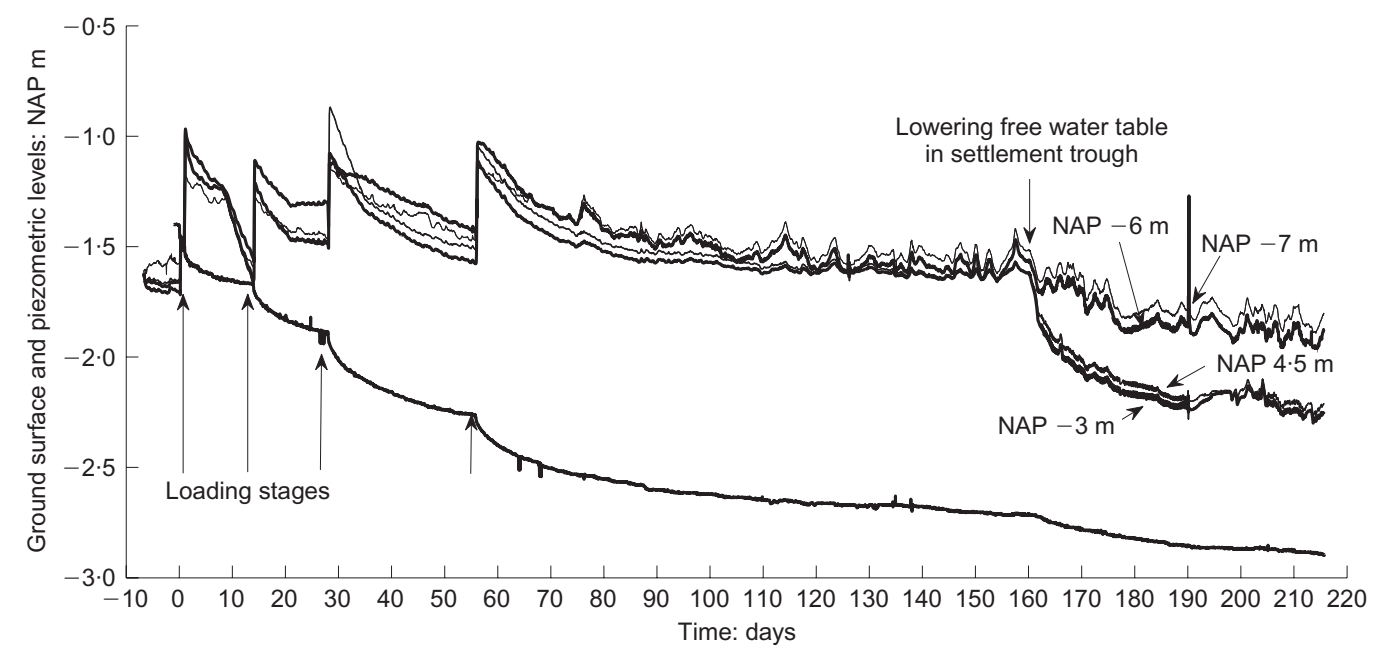

Fig. 12. Settlement and piezometer measurements over pre-loading period of test 6 . Time origin is the start of first surface loading
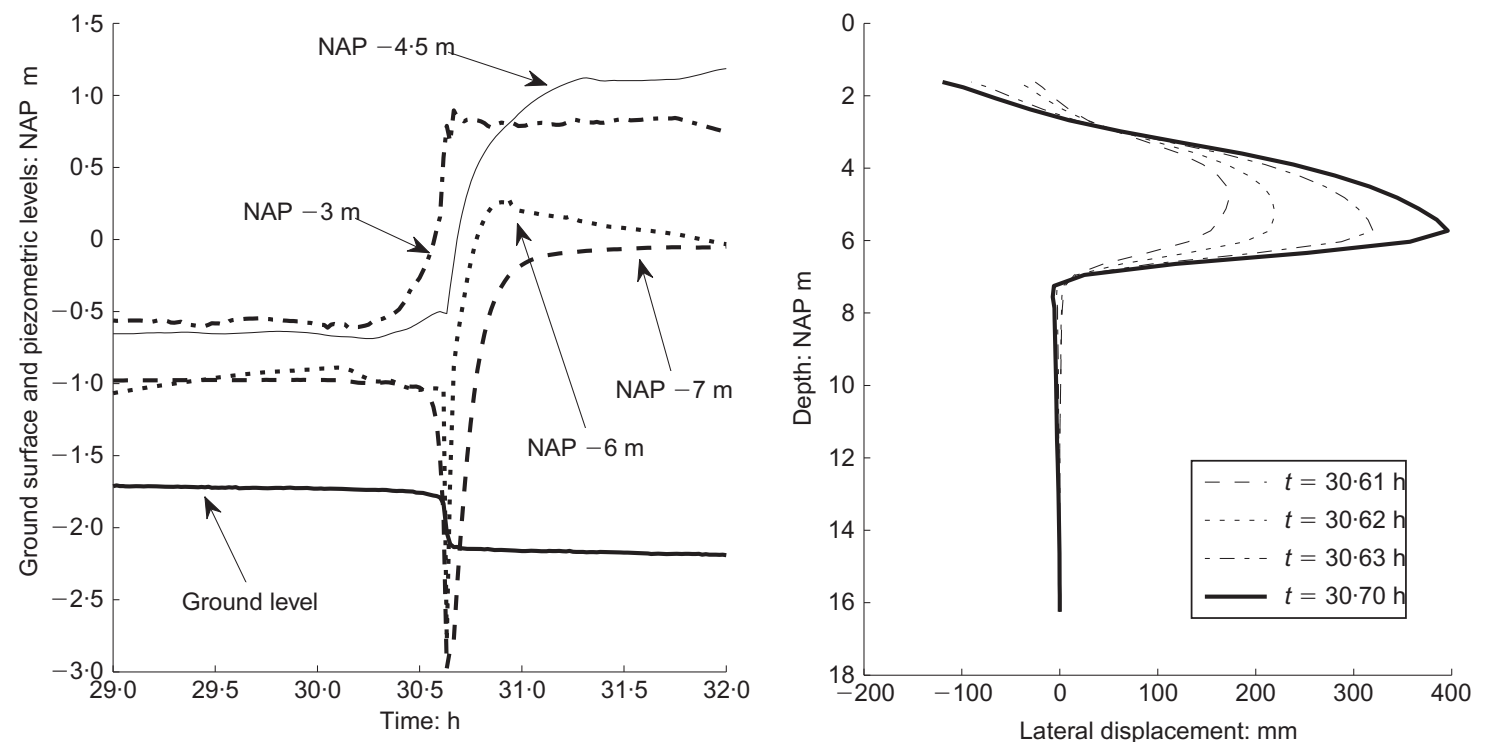

Fig. 13. Settlement, piezometer and inclinometer measurements from final failure stage of test 6 . Time origin is day 216 from Fig. 12. Initial piezometer levels shown as NAP m 


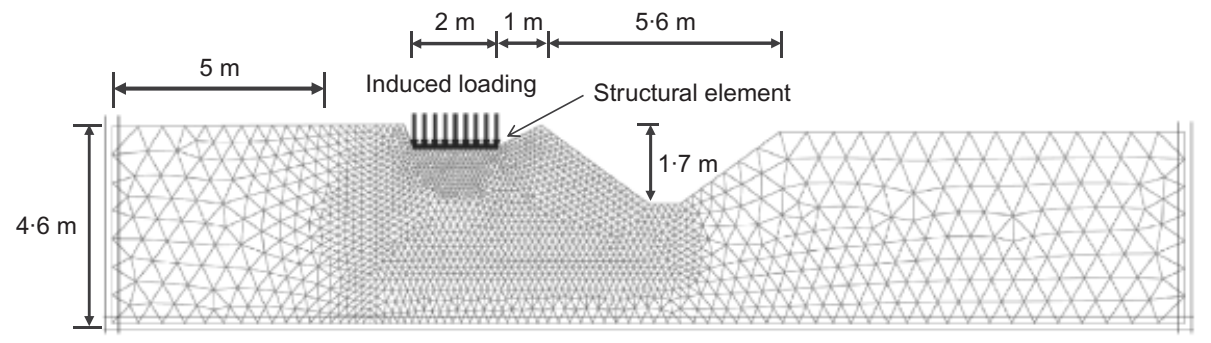

Fig. 14. Finite-element mesh applied in analysis of test 2; similar meshes applied for tests 1,4 and 5, Thick line represents the water table. Boundary conditions; no horizontal displacements on left or right boundary, no vertical displacements on lower boundary. Identical boundary conditions are applied in the following figures

Table 3. Summary of operational Tresca shear strengths found from finite-element analyses

\begin{tabular}{l|r|l}
\hline Analysis & $s_{\mathrm{u}}: \mathrm{kPa}$ & Comments \\
\hline Test 1 & $7 \cdot 4$ & Single-stage operational shear strength, $N_{\mathrm{c}}=3 \cdot 39$ \\
Test 2 & $13 \cdot 3$ & As above, $N_{\mathrm{c}}=3 \cdot 26$ \\
Test 4 & $8 \cdot 5$ & Computed failure mechanism did not capture sliding and toppling of containers 1 and 2 \\
Container 3, no sliding & $8 \cdot 9$ & Assuming uniform $s_{\mathrm{u}}$ in all areas \\
Test 5 & $5 \cdot 5$ & Assumed in OCR $>1$ region \\
Container 4, sliding & $12 \cdot 6$ & Assessed in normally consolidated region \\
Test 6 &
\end{tabular}
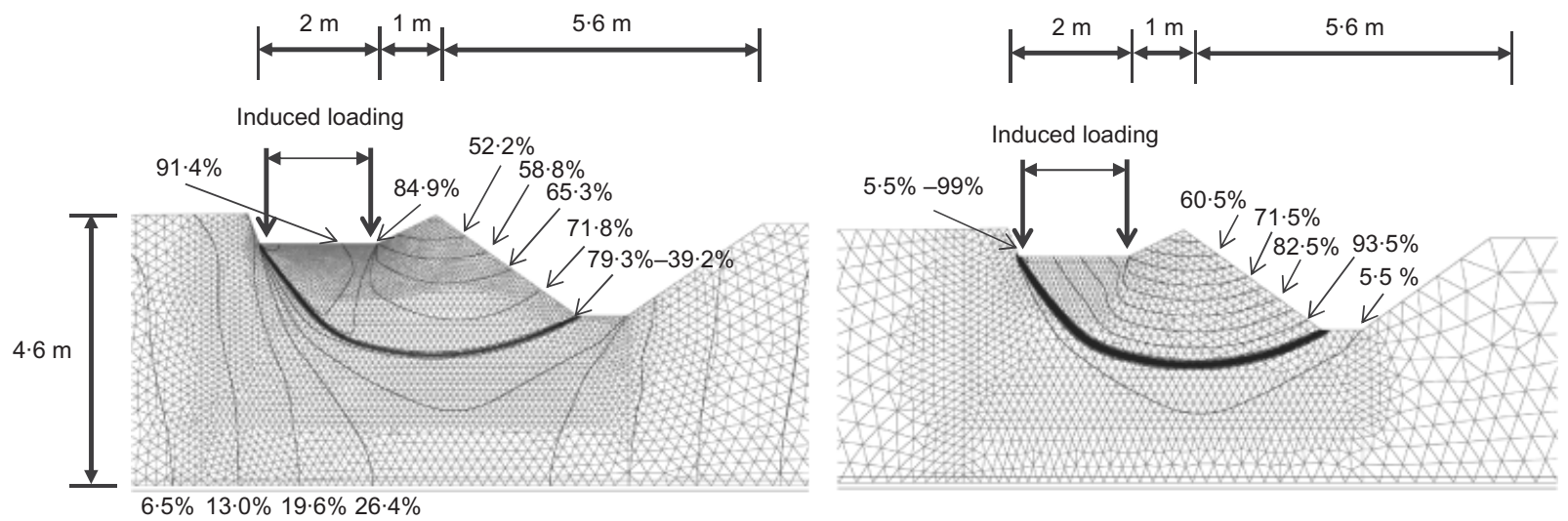

Fig. 15. Predicted failure mechanism indicated by total displacement contours expressed as a percentage of maximum total vector length, for test 1 (left) and test 2 (right)

$$
\left(\frac{s_{\mathrm{u}}}{\sigma_{\mathrm{v}}^{\prime}}\right)_{\text {triax }}=\left(\frac{s_{\mathrm{u}}}{\sigma_{\mathrm{vy}}^{\prime}}\right)_{\mathrm{nc}, \text { triax }}(\mathrm{OCR})^{m}, \quad m=\frac{\mathrm{CR}-\mathrm{RR}}{\mathrm{CR}}
$$

The oedometer tests in Fig. 4(d) indicate an (CR - RR)/ CR of $0 \cdot 87 \pm 6 \%$, indicating that the peat $s_{\mathrm{u}}$ profiles should be relatively insensitive to re-compression effective stresses until $\sigma_{\mathrm{v}}^{\prime}>\sigma_{\mathrm{vy}}^{\prime}$.

Parallel direct simple shear (DSS) tests with Wille (type ASS-1) apparatus included 'Shansep' (stress history and normalised soil engineering properties) experiments (Ladd \& Foot, 1974) on specimens pre-compressed under nominally $K_{0}$ conditions to $50 \mathrm{kPa}$, well beyond initial in situ $\sigma_{\mathrm{vy}}^{\prime}$, before being unloaded to OCRs $1.25,2,5$ and 10 . The samples were failed at shear strain rates of $7.45 \% / \mathrm{h}$ keeping constant height to match undrained conditions (Dyvik et al., 1987). Fig. 17 presents the results. Considering the maximum horizontal shear stress $\tau$ as a proxy for $s_{\mathrm{u}}$, and performing a regression analysis leads to

$$
\left(\frac{s_{\mathrm{u}}}{\sigma_{\mathrm{v}}^{\prime}}\right)_{\mathrm{DSS}}=0 \cdot 47(\mathrm{OCR})^{0.96}
$$

The degree of fit is moderate, giving $R^{2}=0 \cdot 88$. The best-fitting exponent is closer to unity than equation (2) implies. The DSS $s_{\mathrm{u}} / \sigma_{\mathrm{vy}}^{\prime}$ ratio at $\mathrm{OCR}=1$ is 0.47 , conforming to Mesri \& Ajlouni (2007) and Zwanenburg et al. (2012) and falling below the triaxial CIUC $s_{\mathrm{u}} / \sigma_{1 \mathrm{c}}^{\prime}$ ratio, possibly reflecting influences of consolidation style, shear strength anisotropy, the triaxial extrapolation procedure or the imperfect DSS test conditions. Four 'intact' peat DSS tests were conducted after re-consolidation to nominal in situ 'polder' stress conditions with $\sigma_{\mathrm{v}}^{\prime}=5 \mathrm{kPa}$. As shown in Fig. 18, these specimens developed apparently 'dilatant' effective stress paths and, after large strains, peak $\tau$ values of $5.9 \pm 2.3 \mathrm{kPa}$ that fall well below any of the field test $s_{\mathrm{u}}$ values listed in Table 3 . 
Table 4. Details of triaxial tests shown in Fig. 19

\begin{tabular}{l|l|r|r|l}
\hline Sample no. & Depth: m NAP & $w: \%$ & $s_{\mathrm{u}}: \mathrm{kPa}$ & $S_{\mathrm{u}} / \sigma_{\mathrm{vy}}^{\prime}$ \\
\hline 1 & $-4 \cdot 66$ & 1030 & $5 \cdot 52$ & $0 \cdot 63$ \\
2 & $-5 \cdot 49$ & 861 & $29 \cdot 76$ & $0 \cdot 49$ \\
3 & $-4 \cdot 17$ & 1089 & $6 \cdot 68$ & $0 \cdot 60$ \\
4 & $-4 \cdot 02$ & 969 & $7 \cdot 27$ & $0 \cdot 64$ \\
5 & $-2 \cdot 97$ & 949 & $7 \cdot 13$ & $0 \cdot 63$ \\
6 & $-3 \cdot 70$ & 1076 & $12 \cdot 38$ & $0 \cdot 67$ \\
7 & $-2 \cdot 64$ & 878 & $13 \cdot 58$ & $0 \cdot 66$ \\
8 & $-4 \cdot 59$ & 1325 & $17 \cdot 21$ & $0 \cdot 57$ \\
9 & $-4 \cdot 25$ & 851 & $17 \cdot 21$ & $0 \cdot 57$ \\
10 & $-3 \cdot 44$ & 839 & $17 \cdot 21$ & $0 \cdot 52$ \\
11 & $-3 \cdot 62$ & 955 & $18 \cdot 86$ & $0 \cdot 56$ \\
12 & $-3 \cdot 18$ & 1094 & $22 \cdot 96$ & $0 \cdot 75$ \\
13 & $-3 \cdot 28$ & 830 & $23 \cdot 44$ & $0 \cdot 58$ \\
14 & $-3 \cdot 64$ & 719 & $26 \cdot 76$ & $0 \cdot 44$ \\
15 & $-3 \cdot 04$ & 935 & $26 \cdot 41$ & $0 \cdot 70$ \\
16 & $-4 \cdot 22$ & 1410 & $29 \cdot 76$ & $0 \cdot 50$ \\
17 & $-3 \cdot 44$ & 788 & $30 \cdot 93$ & $0 \cdot 61$ \\
18 & $-1 \cdot 98$ & 1103 & $32 \cdot 36$ & $0 \cdot 52$ \\
19 & $-4 \cdot 45$ & 1012 & $34 \cdot 81$ & $0 \cdot 57$ \\
20 & $-3 \cdot 82$ & 1355 & $36 \cdot 00$ & $0 \cdot 59$ \\
21 & $-1 \cdot 80$ & 772 & $47 \cdot 43$ & $0 \cdot 59$ \\
22 & $-1 \cdot 84$ & 879 & $50 \cdot 09$ & $0 \cdot 60$ \\
\hline
\end{tabular}

\section{IN SITU PROBING FIELD TESTS}

Extensive programmes of CPTu, ball penetrometer and field vane soundings were undertaken prior to loading, over the pre-loading periods of tests 4 to 6 and, in some cases, after failure. These permit local correlation with field undrained shear strengths and spatial variability assessment. Lunne et al. (1997) recommend finding best-fitting $N_{k t}$ values from

$$
s_{\mathrm{u}}=\frac{q_{\mathrm{net}}}{N_{k \mathrm{t}}}, \quad q_{\mathrm{net}}=q_{\mathrm{t}}-\sigma_{\mathrm{v} 0}, \quad q_{\mathrm{t}}=q_{\mathrm{c}}+(1+a) u_{2}
$$

where $q_{\mathrm{c}}$ is the uncorrected cone resistance, $a$ is the area ratio ( $=0.59$ here) and $u_{2}$ is the pore pressure measured just above the cone shoulder. The low peat density and the small excess pore pressures induced by penetration led to only small differences between $q_{\mathrm{c}}$ and $q_{\text {net. }}$. BS EN ISO 22476-1
(BSI, 2013) requires that Class $1 \mathrm{CPTu}$ tests record $q_{\mathrm{c}}$ to within $\pm 35 \mathrm{kPa}$ of the true values. Comparing this tolerance with the Uitdam polder $q_{\mathrm{c}}$ range implies measurement errors of up to $35 \%$ could be expected even under the strictest specifications. Additional soundings were therefore conducted with a ball penetrometer to assess whether better resolution and accuracy could be obtained, taking

$$
s_{\mathrm{u}}=\frac{q_{\text {ball }}}{N_{\text {ball }}}
$$

where $q_{\text {ball }}$ is the measured resistance and $N_{\text {ball }}$ is the ball factor.

It is usual to apply significant correction factors to the nominal undrained shear strengths calculated from limit equilibrium analysis of peak field vane test (FVT) to address rate, anisotropy, vane stress non-uniformity and other effects (Bjerrum, 1973; Landva, 2007). Fibre action and partial drainage exacerbate interpretation in peats and Edil (2001) recommends multiplying FVT $s_{\mathrm{u}}$ values by $\mu=0.5$ when assessing foundation stability.

Profiles of $q_{\text {net }}, q_{\text {ball }}$ and uncorrected $s_{\mathrm{u}}^{\mathrm{FVT}}$ recorded at the test 1 and 2 locations are presented in Fig. 19. The CPTu profiles in Fig. 19(a) fluctuate around a nearly constant (gently declining) trend between -2 and $-6.8 \mathrm{~m}$ NAP, without showing any systematic difference between tests 1 and 2. Correlating the mid-depth $q_{\text {net }}$ with the $7 \cdot 3 \mathrm{kPa}$ field test $s_{\mathrm{u}}$ given in Table 3 indicates a best-fitting $N_{k t}^{\text {Field }} \approx 15 \cdot 3$ with local variations of $\pm 30 \%$. The ball profiles show the same features, but with less variation (typically $\pm 20 \%$ ) from their linear trend; an $N_{\text {Ball }}^{\text {Field }} \approx 16.5$ factor is found by matching the mid-depth $q_{\text {ball }}$ with the 'operational field' $s_{\mathrm{u}}=7 \cdot 3 \mathrm{kPa}$ outcome. The uncorrected FVT $s_{\mathrm{u}}$ data plotted in Fig. 19(c) show both larger variations from mean sounding trends and more marked differences between the test locations. Correlating their mid-depth $(13.0$ and $14.6 \mathrm{kPa}) s_{\mathrm{u}}$ values with the $7 \cdot 3 \mathrm{kPa}$ tests 1 and 2 mean foundation failure shear strength confirms that $\mu$ may be taken as $\approx 0.5$ for the Uitdam peats. The FVT results show local variations up to $\pm 40 \%$ and the continuous CPTu and ball tests clearly provide better defined profiles.

Additional $\mathrm{CPTu}$, ball penetrometer and field vane tests were conducted after each test. Ball penetrometer soundings conducted before loading started (profiles S28a and S27a)

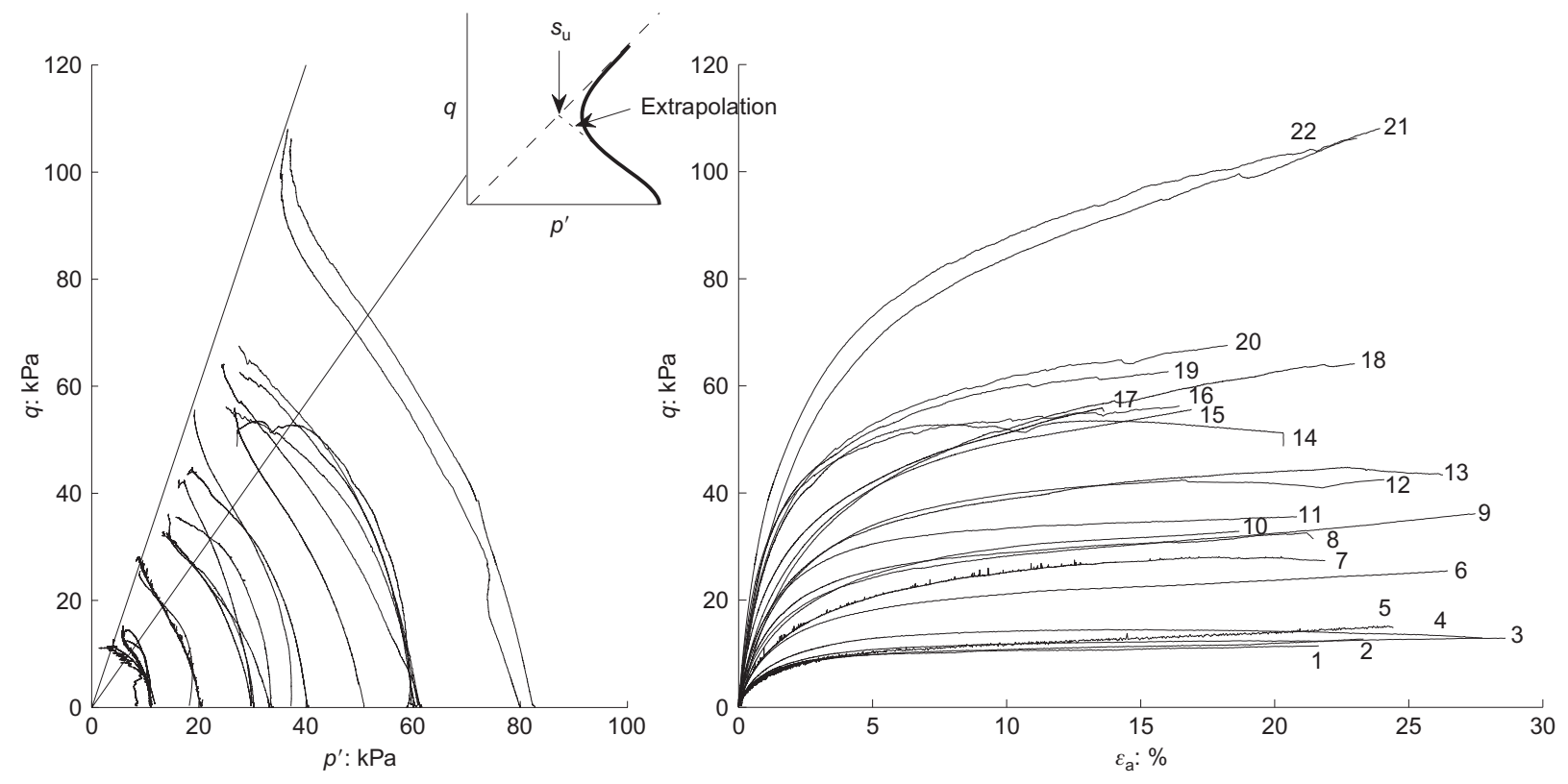

Fig. 16. CIUC triaxial tests on normally consolidated peat samples. Details of samples 1 to 22 are given by Table 4 

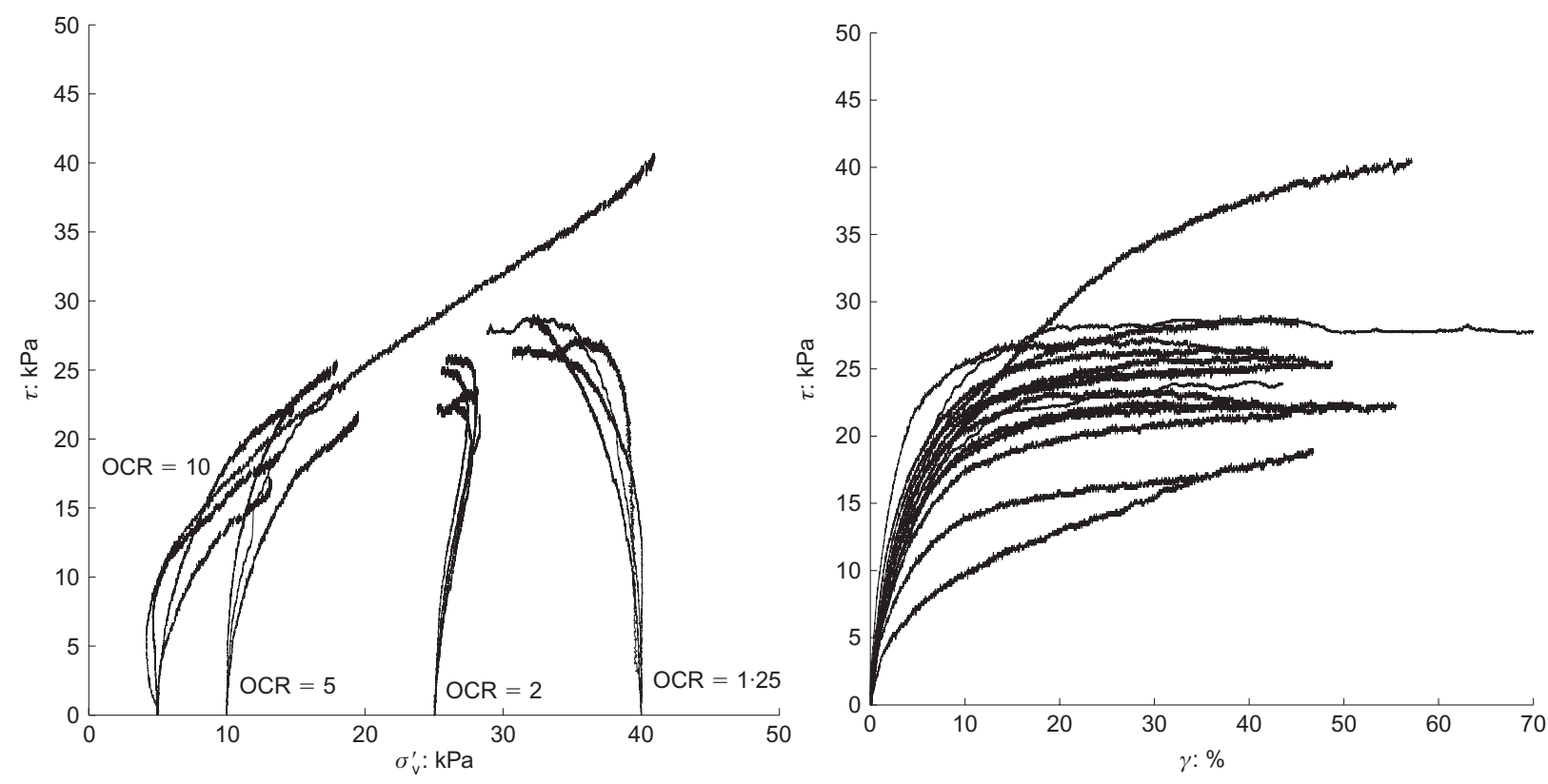

Fig. 17. Shansep DSS tests on peat samples
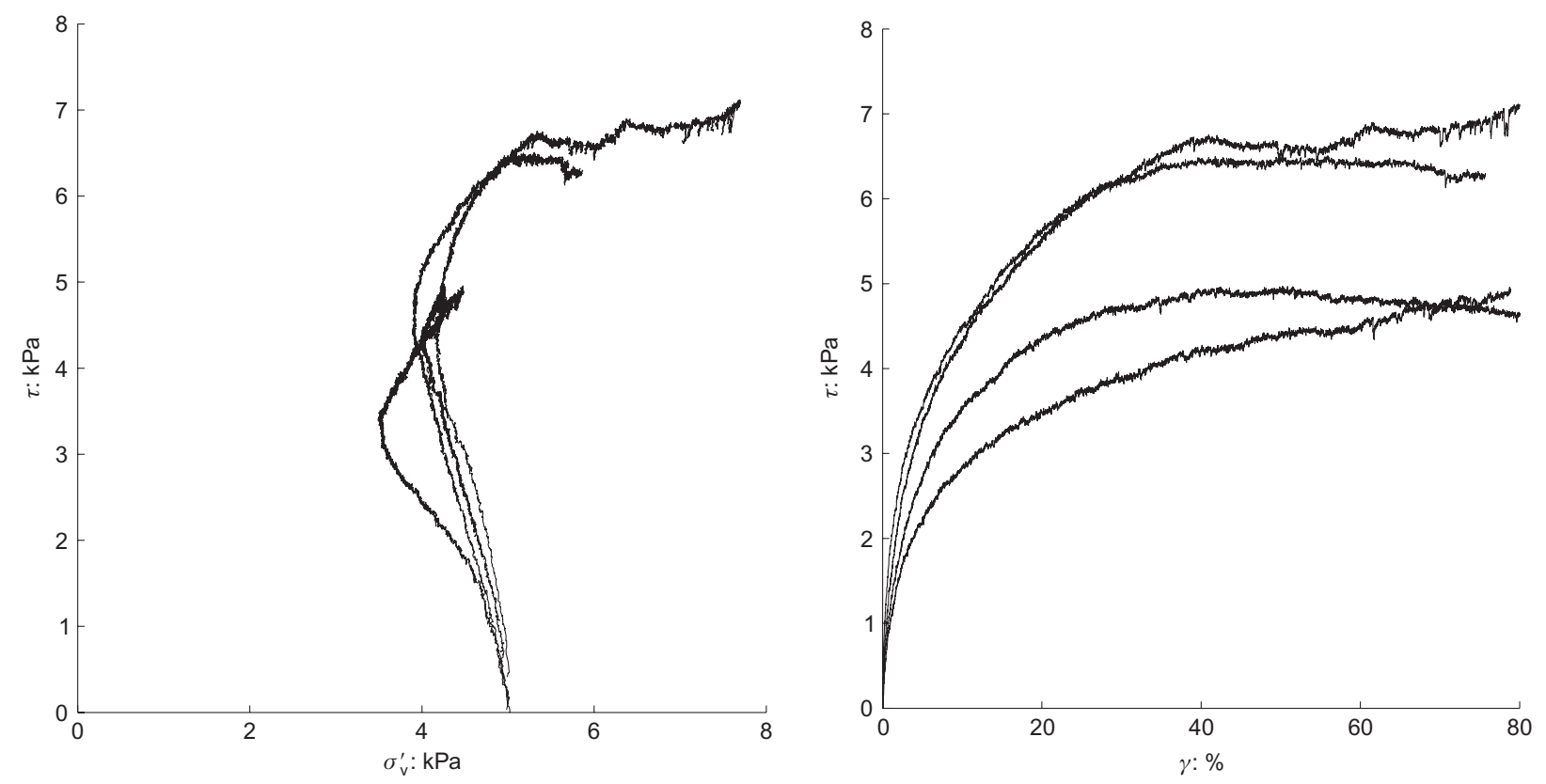

Fig. 18. 'Intact' DSS tests peat samples tested from $\sigma_{\mathrm{v} 0}^{\prime}=5 \mathrm{kPa}$

and 4 days after failure (profiles P2B1 and P2B4) at the test 2 location are shown in Fig. 20. Although the substantial vertical settlement caused by the failure is clear, loading did not lead to any systematic increase in the ball penetrometer resistances. CPTu, ball penetrometer and FVT soundings were also made to either side of the test 6 central loading slab (see Fig. 7) at four stages. Fig. 21 summarises the 'calibrated' $s_{\mathrm{u}}$-depth profiles for the pre-testing April 2012 stage. The calibrated $\mathrm{CPTu}$ and ball penetrometer $s_{\mathrm{u} \text { ave }}$ values are $\approx 5 \mathrm{kPa}$ and $\approx 6 \mathrm{kPa}$, respectively, and the FVT $s_{\mathrm{u}}$ measurements, corrected with $\mu=0 \cdot 5$, scatter more widely around a similar mean $(\approx 5.5 \mathrm{kPa})$ that falls significantly below the $s_{\mathrm{u} \text { ave }} \approx 7 \cdot 3 \mathrm{kPa}$ assessed from tests 1 and 2 . The in situ testing supports the earlier inference from the foundation load tests that the test 6 polder had a marginally weaker initial $s_{\mathrm{u}}$ profile than that applying to tests 1 and 2 . However, consolidation led to higher probing resistances developing under the pre-loaded areas of test 6. Fig. 22 shows the CPTu and ball penetrometer profiles measured after 190 days of pre-loading, with respective $s_{\mathrm{u}}$ ave values of 8-9 and 13-14 $\mathrm{kPa}$, respectively, under the edges of the central loading slabs. The overall mean $s_{\mathrm{u}}(11 \pm 3 \mathrm{kPa})$ is double the mean 'local initial polder' value of $5.5 \mathrm{kPa}$ noted above. The generally more scattered final FVT $s_{\mathrm{u}}$ measurements plotted in Fig. 22 also indicate a similar doubling of shear strength due to consolidation.

The above laboratory and field measurements suggest how the multi-stage field loading tests may be analysed, albeit in an approximate and preliminary way, by adopting a 'Shansep' consolidated undrained shear approach in which the peat $s_{\mathrm{u}}$ varies in accordance with the local degree of consolidation under pre-loading. This treatment is applied to test 6 as simply as possible by assuming: (a) 'undisturbed OCR $>1$ ' polder shear strengths apply in areas where the 

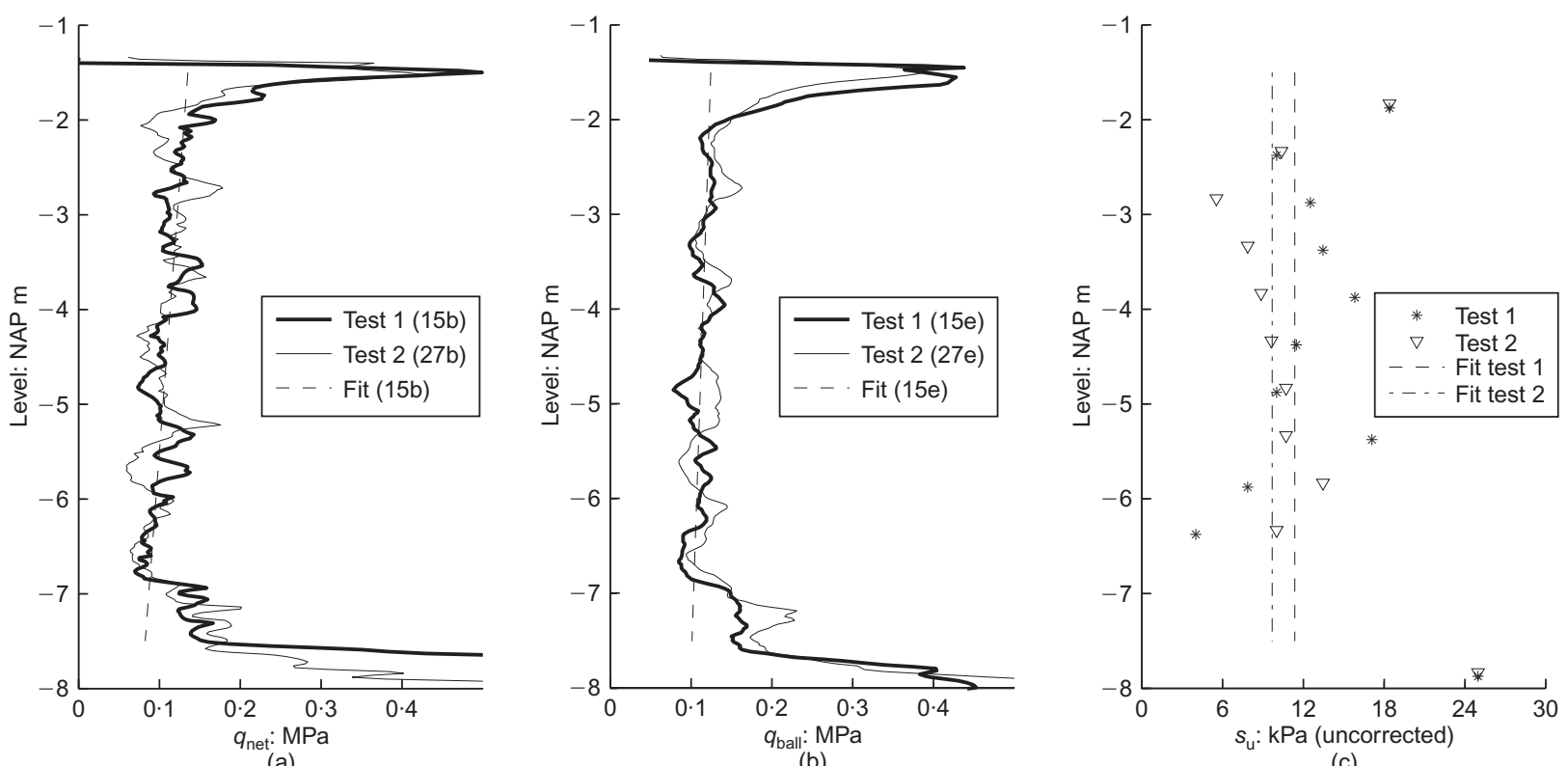

Fig. 19. Pre-testing in situ $s_{\mathrm{u}}$ profiles for test 1 and 2 areas from: (a) CPTu, $q_{\text {net }}$; (b) ball penetrometer, $q_{\text {ball; }}$ (c) field vane, uncorrected $s_{\mathrm{u}}$

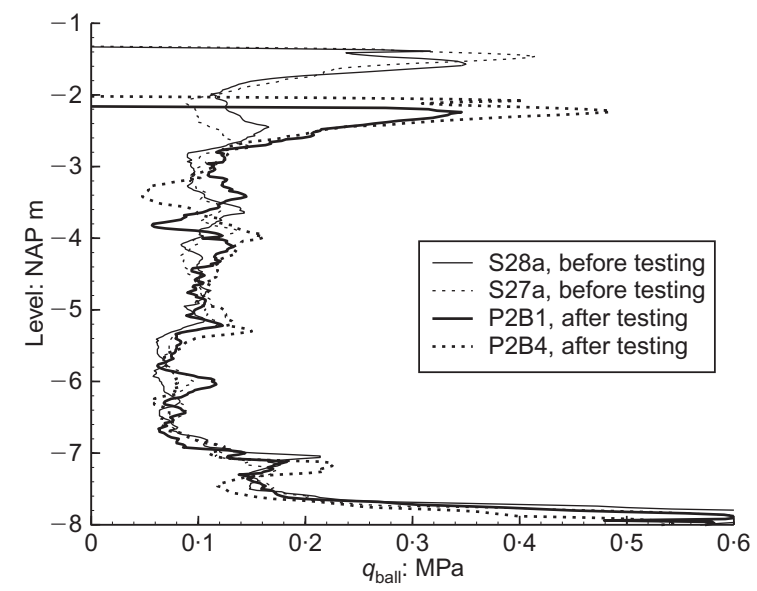

Fig. 20. Comparison of ball penetrometer tests conducted before, S27a and S28a, and after, P2B1 and P2B4, test 2 vertical effective stresses remain below $\sigma_{\mathrm{vy}}^{\prime}$ and $(b)$ a raised average undrained shear strength in the $\mathrm{OCR}=1$ areas where $\sigma_{\mathrm{v}}^{\prime}>\sigma_{\mathrm{vy}}^{\prime}$. It is recognised that analyses which address evolving shear strength anisotropy and time effects explicitly would offer additional insights; see Jardine et al. (1997), Zdravkovic \& Jardine (2001) or Lehane \& Jardine (2003). Drained finite-element calculations were run with a MohrCoulomb model to estimate the $\sigma_{\mathrm{v}}^{\prime}$ distributions acting at day 217, after full pore pressure dissipation and shortly before test 6 was brought to failure. The calculated isobars indicate how ' $\mathrm{OCR}=1$ ' and 'OCR $>1$ ' zones can be delineated, resulting in the ' $\mathrm{OCR}=1$ ' region boundary indicated in Fig. 23. Tresca analyses were made with different shear strengths applied in the two zones. Noting the 'punching shear' failure system illustrated in Fig. 24, it was considered possible that the failure may have engaged the top of the organic clay layer. Parametric analyses were undertaken that varied the organic clay's thickness and $s_{\mathrm{u}}$

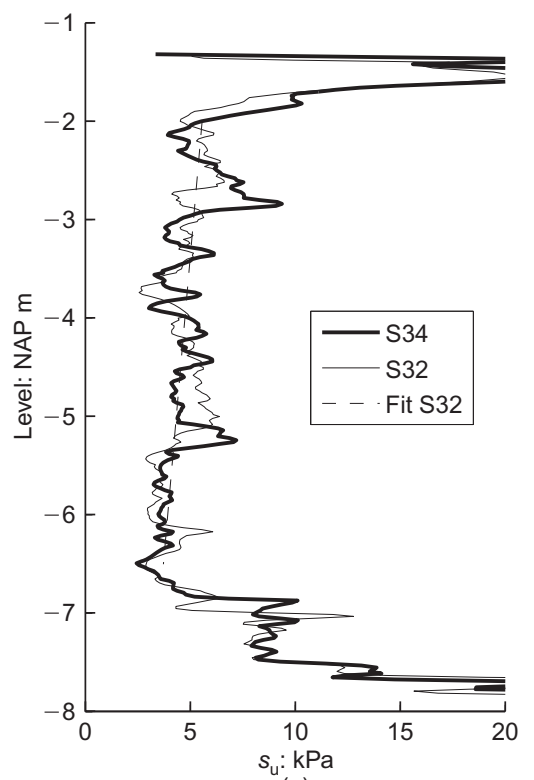

(a)

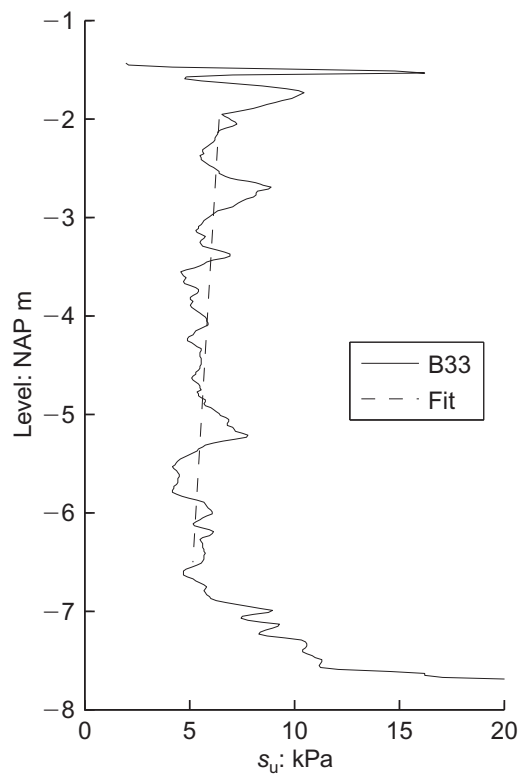

(b)

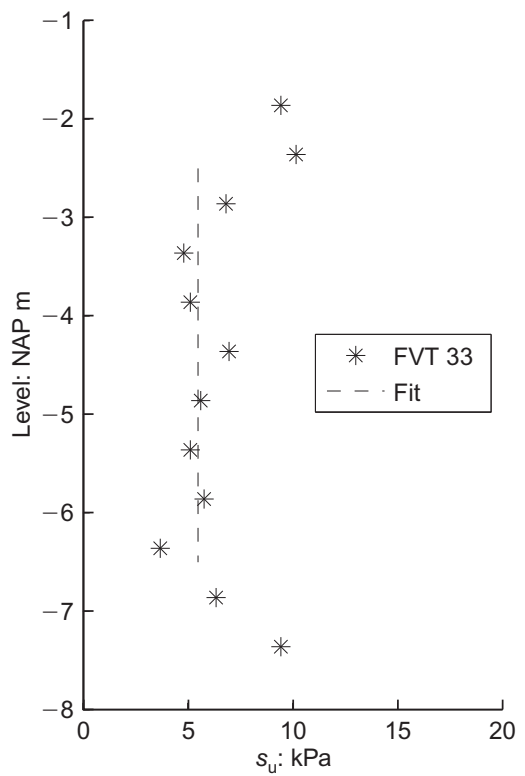

(c)

Fig. 21. Pre-testing in situ $s_{\mathrm{u}}$ profiles for test 6 area from: (a) CPTu $q_{\text {net }}$; (b) ball penetrometer $q_{\text {ball; }}$ (c) field vane, corrected $s_{\mathrm{u}}$ 


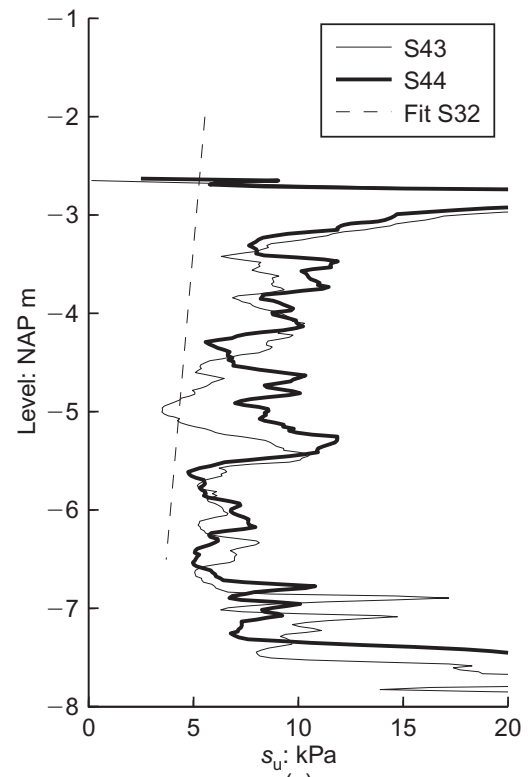

(a)

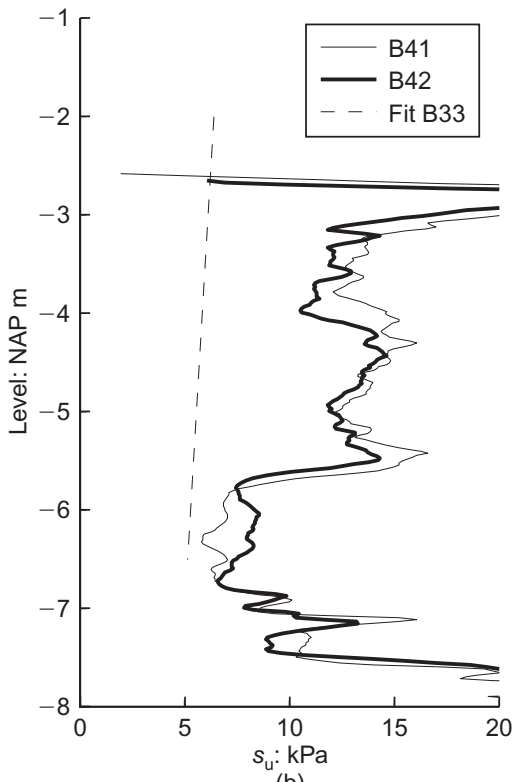

(b)

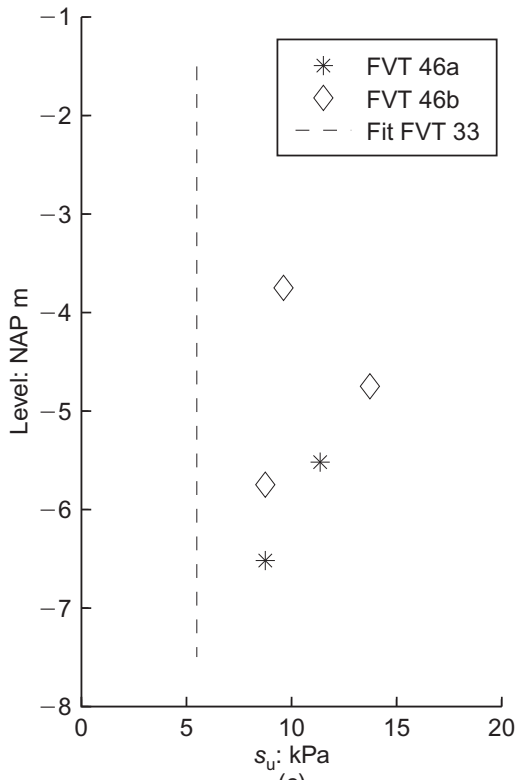

(c)

Fig. 22. In situ probing $s_{\mathrm{u}}$ profiles for test 6 area after pre-loading from: (a) CPTu $q_{\text {net }}$ (b) ball penetrometer $q_{\mathrm{ball}}$ at day 190 ; (c) field vane corrected $s_{\mathrm{u}}$ from post-failure day 227

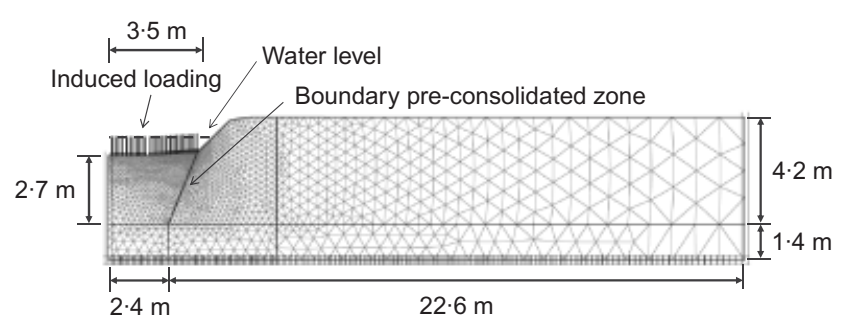

Fig. 23. Mesh applied in analysis of test 6

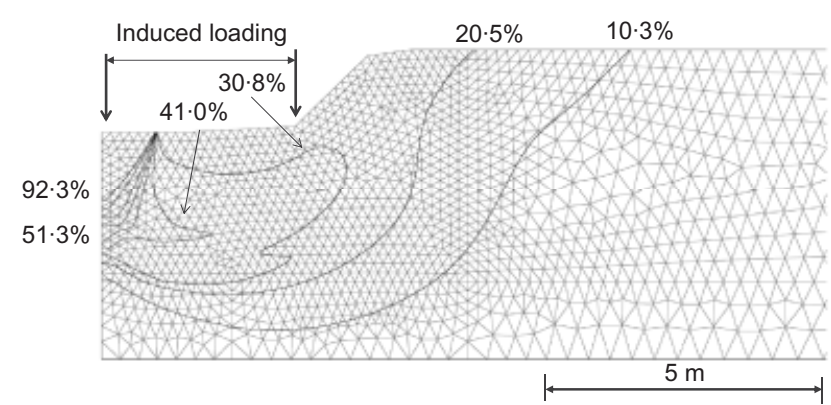

Fig. 24. Failure mechanism, total displacement contours expressed as a percentage of maximum total vector length, calculated for test 6

between 1 and $5 \mathrm{~m}$ and $7 \cdot 3$ and $8.5 \mathrm{kPa}$, respectively, to assess the possible impact on the results obtained. The partitioned back-analysis of test 6 assumed (from the 'calibrated' in situ tests described above) $s_{\mathrm{u} \text { ave }}=5.5 \mathrm{kPa}$ in the OCR $>1$ peat. As listed in Table 3 , this led to a mean $s_{\mathrm{u}}=12 \cdot 6 \mathrm{kPa}$ in the normally consolidated 'pre-loaded' area, which conforms with the test 4 outcome and in situ testing profiling summarised in Fig. 22. Correlating the latter 'OCR $=1$ ' region $s_{\mathrm{u}}$ with the average vertical stresses applying prior to the final loading stage (from Fig. 23) in the same region indicates a normally consolidated (denoted by subscript NC) $\left(s_{\mathrm{u}} / \sigma_{\mathrm{vy}}^{\prime}\right)_{\mathrm{NC}} \approx 0.60$ and initial 'polder' $\sigma_{\mathrm{vy}}^{\prime}=10.9 \mathrm{kPa}$, which matches the oedometer test profile given in Fig. 4(e).

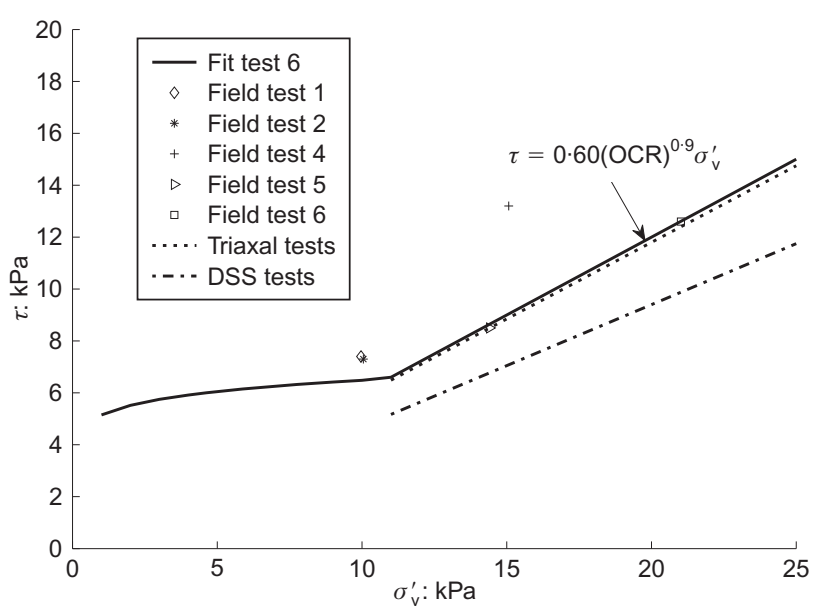

Fig. 25. Overall simplified field test shear strength interpretation. The 'triaxial tests' normally consolidated line is given by $\left(s_{\mathrm{u}} / \sigma_{1 \mathrm{c}}^{\prime}\right)_{\text {triax }}=0.59$ and the 'DSS test' line $\left(s_{\mathrm{u}} / \sigma_{\mathrm{v}}^{\prime}\right)_{\mathrm{DSS}}=0 \cdot 47$

Figure 25 summarises the field tests' outcomes by plotting a $s_{\mathrm{u}}-\sigma_{\mathrm{v}}^{\prime}$ relationship for the test 6 area, applying equation (2) with $m=0.9$ and the laboratory test results, $\left(s_{\mathrm{u}} / \sigma_{1 \mathrm{c}}^{\prime}\right)_{\text {triax }}=0.59$ and $\left(s_{\mathrm{u}} / \sigma_{\mathrm{v}}^{\prime}\right)_{\mathrm{DSS}}=0 \cdot 47$. Also shown are the other Table $3 s_{\mathrm{u}}$ values plotted against best estimates for the mean vertical effective stress applying over each field test's failure surface, accounting for the computed total stress distributions and pore pressures measured shortly before each undrained failure. The test 5 results are compatible with the test 6 relationship. The mean $s_{\mathrm{u}}$ gauged from test 4 exceeds that found in other tests. However, test 4 did not fail in a uniform manner and its apparent collapse load may have been raised by three-dimensional side-restraining effects.

Overall, it appears that undrained shear strengths can be assessed for the apparently over-consolidated peats found in the polder areas from multiple in situ test profiles interpreted with the above calibrated $N_{k t}$ and FVT factors. Fig. 25 shows that it also appears to be possible to predict the operational shear strengths available under other conditions appear by applying a Shansep approach based on oedometer yield stresses and normally consolidated $s_{\mathrm{u}} / \sigma_{\mathrm{v}}^{\prime}$ ratios developed 
Table 5. Applied material properties

\begin{tabular}{|c|c|c|c|}
\hline & & $\begin{array}{c}\text { Test } 6 \text { (pre-load } \\
\text { conditions) }\end{array}$ & $\begin{array}{c}\text { Test } 5 \text { (initial } \\
\text { conditions) }\end{array}$ \\
\hline \multirow[t]{6}{*}{ Peat } & $E: \mathrm{kPa}$ & 600 & 500 \\
\hline & & $0 \cdot 15$ & $0 \cdot 15$ \\
\hline & $\gamma: \mathrm{kN} / \mathrm{m}^{3}$ & $10 \cdot 5$ & $10 \cdot 1$ \\
\hline & $k: \mathrm{m} /$ day & 0.0075 & $0 \cdot 25$ \\
\hline & $E_{\text {oed }}{ }^{*} \mathrm{kPa}$ & 634 & 528 \\
\hline & $c_{\mathrm{v}}:^{*} \mathrm{~m}^{2} /$ year & 177 & 4915 \\
\hline \multirow[t]{6}{*}{ Clay } & $E: \mathrm{kPa}$ & 1000 & 1000 \\
\hline & & $0 \cdot 33$ & $0 \cdot 33$ \\
\hline & $\gamma: \mathrm{kN} / \mathrm{m}^{3}$ & 13 & 13 \\
\hline & $k:^{*} \mathrm{~m} /$ day & $7 \times 10^{-4}$ & $7 \times 10^{-4}$ \\
\hline & $E_{\text {oed }} *^{*} \mathrm{kPa}$ & 1482 & 1482 \\
\hline & $c_{\mathrm{v}}:^{*} \mathrm{~m}^{2} /$ year & 39 & 39 \\
\hline
\end{tabular}

* Calculated from $E, v$ and $k$. from either triaxial or DSS tests, when interpreted as outlined earlier. It is interesting that the $s_{\mathrm{u}} / \sigma_{\mathrm{v}}^{\prime}$ ratios far exceed the operational ranges found with clays; see for example Jardine (2002). Integrating a range of laboratory and in situ approaches reduces the significant scatter associated with any single technique and allows local variations in peat initial conditions to be considered.

\section{SUMMARY AND CONCLUSIONS}

The Uitdam study was designed to investigate the fullscale behaviour of thick and relatively uniform peats under single and multi-stage surface loading. The main conclusions are listed below.

(a) The full-scale instrumented field trials demonstrated the consolidation, load-deformation and shear failure behav-

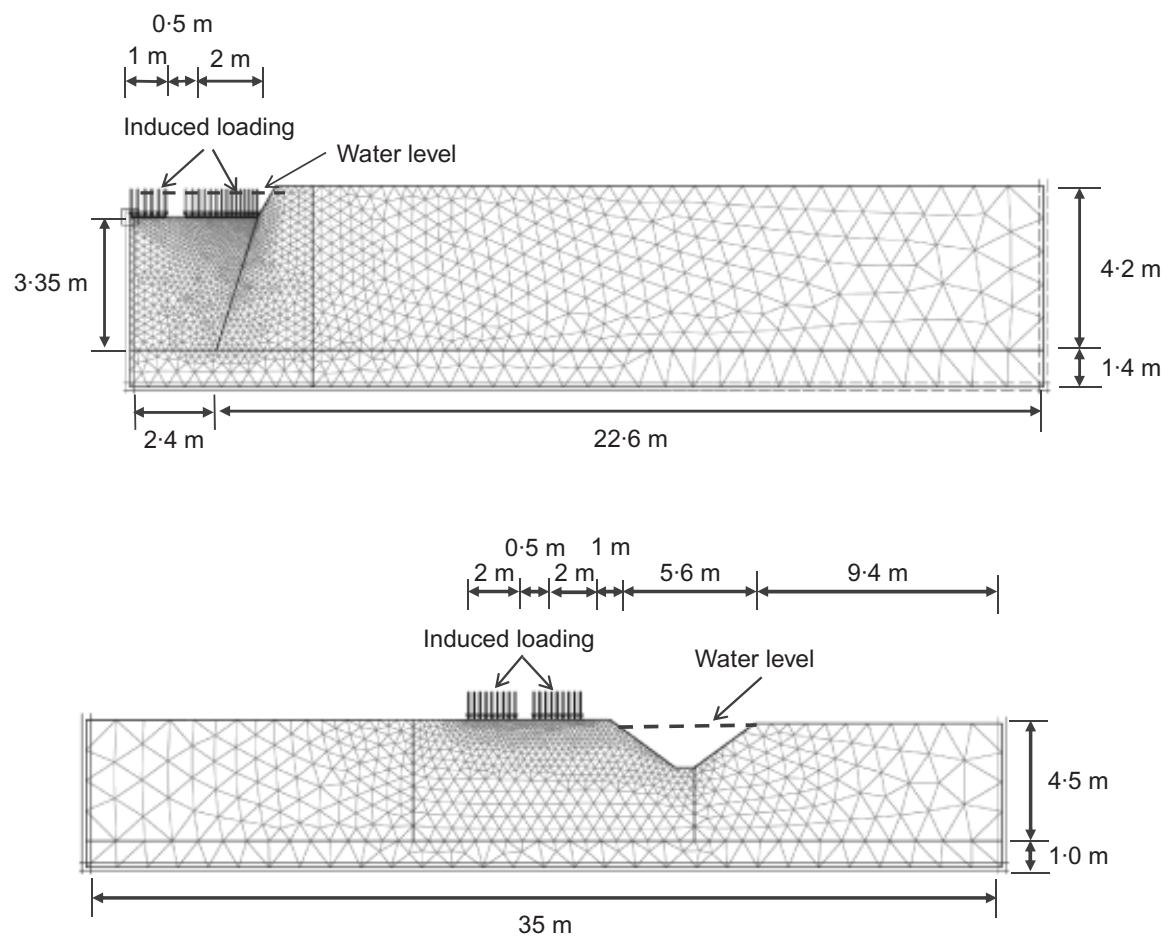

Fig. 26. Finite-element mesh applied for consolidation analysis: test 6 above, test 5 below
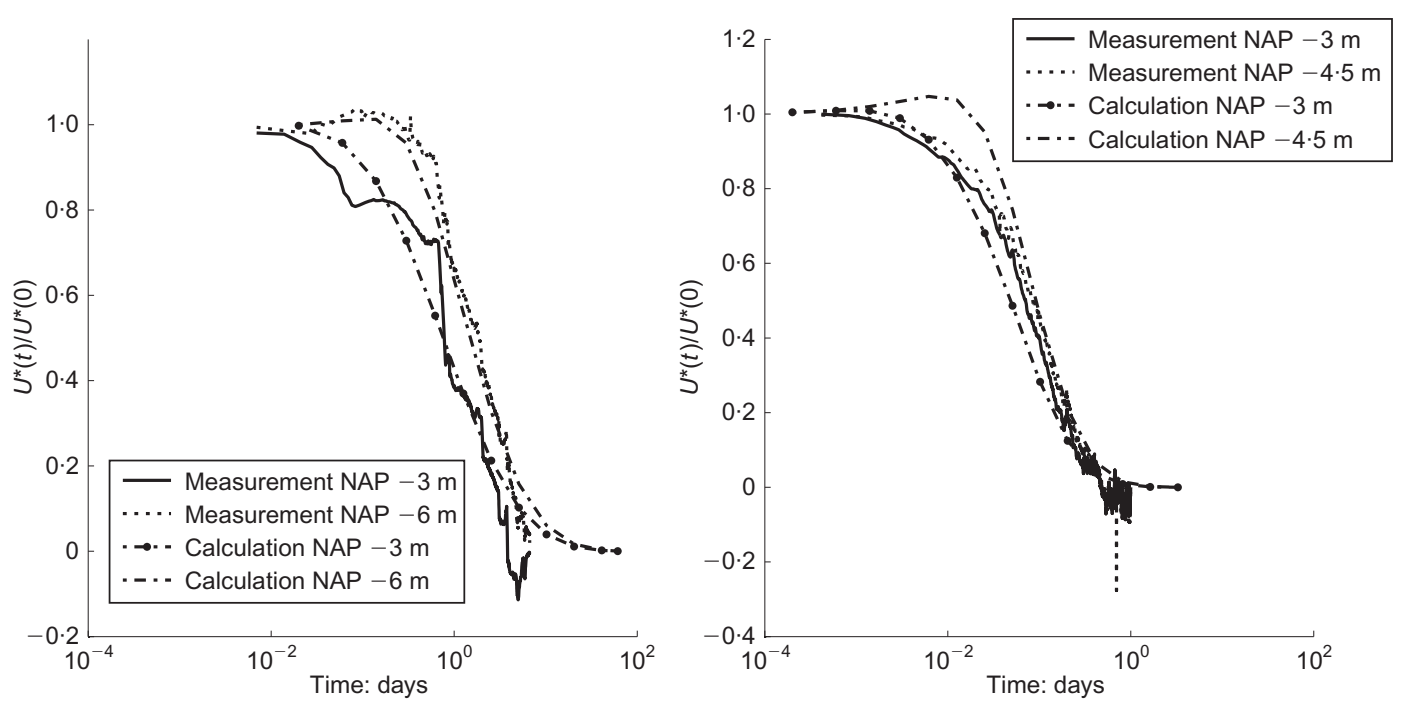

Fig. 27. Consolidation analysis of excess pore pressure $\left(U^{*}\right)$ dissipation, left test 5 , non-preloaded case; right test 6 , pre-loaded case 
iours of foundations loaded on peat under single and multi-stage conditions.

(b) Simple Tresca-based, numerical back-analysis led to representative operational $s_{\mathrm{u}}$ ranges that allowed a spread of laboratory and in situ determination techniques to be assessed. CPTu and ball penetrometer factors of $N_{k \mathrm{t}}^{\text {Field }} \approx 15$ and $N_{\text {Ball }}^{\text {Field }} \approx 16$ were found and the $\mu=0 \cdot 5$ correction factor for FVT measurements was confirmed.

(c) Individual probing tests showed substantial variations around mean $s_{\mathrm{u}}$ profile trends of $\pm 30,20$ and $40 \%$ for the $\mathrm{CPTu}$, ball and FVT devices, respectively. Mean trends were best defined from continuous sounding profiles. Undertaking multiple soundings with different devices reduces measurement uncertainty and addresses spatial variations, which were found to be significant across the apparently uniform Uitdam test area.

(d) Pre-loading and compressing the peat (by up to $35 \%$ in test 6) led to significant improvements in bearing capacity, with in situ probing tests indicating a near doubling of operational undrained shear strength. These features were explored and verified in analyses that differentiated between the shear strengths available in the $\mathrm{OCR}=1$ and over-consolidated zones of the peat mass. The outcome suggested an average $s_{\mathrm{u}} / \sigma_{\mathrm{vy}}^{\prime} \approx 0.60$ for normally consolidated conditions that falls close to that interpreted from CIUC triaxial laboratory tests and marginally above the mean DSS test trend.

(e) The field experiments provided valuable information on ground movement and pore pressure trends. A numerical analysis of the pre-loading test data indicated relatively short initial consolidation times that gradually extended as loading levels increased. A global peat $c_{\mathrm{V}}$ value around $177 \mathrm{~m}^{2} /$ year was interpreted for the final loading stage of test 6 through numerical back-analysis.

( $f$ ) Considerable scope exists to extend the preliminary analyses with fully coupled approaches, large strain modelling and more sophisticated constitutive laws. Such modelling could address both ground movements and the interplay between consolidation and stability. Further careful laboratory testing is also required to investigate the degree of anisotropy in the peats' mechanical behaviour, assess strain rate dependency and investigate any significant effects of the peats' natural structure that may influence field behaviour.

\section{ACKNOWLEDGEMENTS}

The authors acknowledge the Dutch Ministry of Public Works (Rijkswaterstaat-WVL) and the HHNK Water Authority for commissioning and financing the field tests. Thanks are also due to colleagues at Deltares for helping to run tests and analyse the data. The authors would like to thank G.A.M. Kruse for describing the failure mechanisms from the trial pit and Dr G. Erkens for preparing Fig. 3.

\section{APPENDIX. QUANTITATIVE EVALUATION OF \\ OBSERVED CONSOLIDATION RATES}

The decay of excess pore pressure observed after application of the loading steps applied in tests 5 and 6 was analysed through a series of finite-element calculations considering the range from $(a)$ the first (lightly loaded) step of test 5 and $(b)$ the last (most heavily loaded) step of test 6 . For the first case a load of $13 \cdot 3 \mathrm{kPa}$ was applied to the rigid slabs. For the second, a load increment of $6.66 \mathrm{kPa}$ was applied. The latter loading step was applied after accounting for $0.85 \mathrm{~m}$ settlement, with $\approx 18 \%$ vertical strain in the peat.

As described in the main text, slightly different Young's moduli were assumed to apply outside and underneath the loaded areas. The peat and underlying clay layer were modelled with the linear properties listed in Table 5 that were derived from the laboratory tests, as summarised in Table 4. Fig. 26 shows the meshes applied for both analyses. The permeability values were then varied to achieve good fits with the field data. For the 'non-preloaded' test 5 case the best-fitting permeability was $2.9 \times 10^{-6} \mathrm{~m} / \mathrm{s}$, slightly higher than given by the falling head tests. The best-fitting permeability dropped to $8.68 \times 10^{-8} \mathrm{~m} / \mathrm{s}$ at approximately $18 \%$ strain in the most heavily loaded area of peat in the test 6 analysis.

Figure 27 compares the excess pore pressure dissipation calculations with the field measurements, considering for test 5 piezometers initially installed to NAP $-3 \mathrm{~m}$ and NAP $-6 \mathrm{~m}$. Note also that the test 6 piezometer placed at NAP $-6 \mathrm{~m}$ was probably pushed down into in the underlying clay layer by settlement, inducing friction along its installation shaft which extended to the ground surface. Comparisons were therefore made at NAP $-3 \mathrm{~m}$ and $-4.5 \mathrm{~m}$ for the test 6 case.

\section{NOTATION}

$a$ area ratio of CPT cone, see equation (4)

$C_{\alpha \mathrm{e}}$ creep coefficient

$C_{\mathrm{c}}$ compression modulus for normal consolidated behaviour, based on void ratio

CR compression modulus for normal consolidated behaviour, based on vertical strain

$c_{\mathrm{V}}$ consolidation coefficient $\left(\mathrm{m}^{2} /\right.$ year $)$

$d$ thickness of concrete slabs $(d=0.14 \mathrm{~m})$

$E$ Young's modulus $(\mathrm{kPa})$

$E_{\text {oed }}$ Young's modulus for confined loading conditions $(\mathrm{kPa})$

$E_{50 \text {,undrained }}$ Young's modulus, from mid-points of triaxial tests $(\mathrm{kPa})$

EA axial stiffness $(\mathrm{kN} / \mathrm{m})$

EI flexural rigidity $\left(\mathrm{kN} \mathrm{m}^{2} / \mathrm{m}\right)$

$e$ void ratio

$K_{0}$ ratio of horizontal to vertical effective stress

$k$ permeability ( $\mathrm{m} /$ day)

$M$ slope of critical state line

$m$ (CR - RR)/RR, see equation (2)

$N$ loss on ignition (\%)

$N_{\text {ball }}$ ball factor, see equation (5)

$N_{\mathrm{c}}$ bearing coefficient, see equation (1)

$N_{k \mathrm{t}}$ cone factor, see equation (4)

$p^{\prime}$ isotropic effective stress $(\mathrm{kPa})$

$q$ deviator stress $(\mathrm{kPa})$

$q_{\text {ball }}$ ball penetrometer resistance ( $\mathrm{MPa}$ or $\mathrm{kPa}$ ), see equation (5)

$q_{\mathrm{c}}$ uncorrected cone resistance ( $\mathrm{MPa}$ or $\mathrm{kPa}$ ), see equation (4)

$q_{\text {net }}$ net cone resistance ( $\mathrm{MPa}$ or $\mathrm{kPa}$ ), see equation (4)

$q_{\mathrm{t}}$ corrected cone resistance (MPa or $\mathrm{kPa}$ ), see equation (4)

$q_{\mathrm{u}}$ failure load $(\mathrm{kPa})$, see equation (4)

$R^{2}$ regression factor

RR compression modulus for reloading, based on vertical strain

$s_{\mathrm{u}} \quad$ undrained shear strength $(\mathrm{kPa})$

$U^{*}$ excess pore pressure $(\mathrm{kPa})$

$u_{2}$ pore pressure measured behind the cone $(\mathrm{kPa})$, see equation (4)

$w$ water content $(\%)$

$\gamma$ unit weight $\left(\mathrm{kN} / \mathrm{m}^{3}\right)$

$\mu$ correction factor field vane test

$v$ Poisson ratio

$\rho$ density $\left(\mathrm{Mg} / \mathrm{m}^{3}\right)$

$\sigma_{1}^{\prime}, \sigma_{2}^{\prime}, \sigma_{3}^{\prime}$ principal stresses $(\mathrm{kPa})$

$\sigma_{\mathrm{r}}^{\prime}$ radial effective stress $(\mathrm{kPa})$

$\sigma_{\mathrm{V}}^{\prime} \quad$ vertical effective stress $(\mathrm{kPa})$

$\sigma_{\mathrm{v} 0}$ in situ vertical stress $(\mathrm{kPa})$

$\sigma_{\mathrm{v} 0}^{\prime}$ in situ vertical effective stress $(\mathrm{kPa})$

$\sigma_{\text {vy }}^{\prime} \quad$ vertical yield stress $(\mathrm{kPa})$

$\tau$ shear stress $(\mathrm{kPa})$

$\phi^{\prime}$ friction angle (degrees)

\section{REFERENCES}

Becker, D. E., Crooks, J. H. A., Been, K. \& Jefferies, M. G. (1987). Work as a criterion for determining in situ and yield stress in clays. Can. Geotech. J. 24, No. 4, 549-564. 
Begemann, H. K. S. (1971). Soil sampler for taking undisturbed sample $66 \mathrm{~mm}$ in diameter and with a maximum length of $17 \mathrm{~m}$. Proceedings of the 4th Asian ISSMFE conference, specialty session quality in soil sampling, Bangkok, pp. 54-57. Melbourne, Australia: International Group on Soil Sampling.

Bjerrum, L. (1973). Problems of soil mechanics and construction on soft clays and structurally unstable soils (collapsible, expansive and others). Proceedings of the 8th ICSMFE, Moscow, vol. 3, pp. 111-159.

Boylan, N., Long, M. \& Mathijssen, F. A. J. M. (2011). In situ strength characterisation of peat and organic soil using full flow penetrometers. Can. Geotech. J. 48, No. 7, 1085-1099.

BSI (2013). BS EN ISO 22476-1:2012: Geotechnical investigation and testing. Field testing. Electrical cone and piezocone penetration test. London, UK: BSI.

Davis, E. H. \& Booker, J. R. (1973). The effect of increasing strength with depth on the bearing of clays. Géotechnique $\mathbf{2 3}$, No. 4, 551-563, http://dx.doi.org/10.1680/geot.1973.23.4.551.

Den Haan, E. J. \& Kruse, G. A. M. (2006). Characterisation and engineering properties of Dutch peats. Proceedings of the 2nd international workshop on characterisation and engineering of natural soils, Singapore, vol. 3, pp. 2101-2133. London, UK: Taylor and Francis.

Dyvik, R., Berre, T., Lacasse, S. \& Raadim, B. (1987). Comparison of truly undrained and constant volume direct simple shear tests. Géotechnique 37, No. 1, 3-10, http://dx.doi.org/10.1680/geot. 1987.37.1.3.

Edil, T. B. (2001). Site characterization in peat and organic soils. Proceedings of the international conference on in situ measurement of soil properties and case histories (eds P. P. Rahardjo and T. Lunne), pp. 49-59. Bali, Indonesia: Parahyangan Catholic University.

Georgiadis, K. (2010). Undrained bearing capacity of strip footings on slopes. J. Geotech. Geoenviron. Engng 136, No. 7, 677-685.

Jardine, R. J. (2002). Stability and Instability: soft clay embankment foundations and offshore continental slopes. Keynote Paper. International symposium on coastal geotechnical engineering in practice, Yokohama, vol. 2, pp. 99-118. Rotterdam, the Netherlands: Balkema.

Jardine, R. J., Zdravkovic, L. \& Porovic, E. (1997). Anisotropic consolidation, including principal stress axis rotation: experiments, results and practical implications. Proceedings of the 14th ICSMFE, Hamburg (eds A. Nakase and T. Tsuchida), vol. IV, pp. 2165-2168. Lisse, the Netherlands: Swets and Zeitlinger.

Ladd, C. C. \& Foot, R. (1974). A new design procedure for stability of soft clays. J. Geotech. Engng Div., ASCE 100, No. GT7, 763-786.

Landva, A. O. (2007). Characterization of Escuminac peat and construction on peatland. In Characterisation and engineering properties of natural soils (eds T. W. Tan, K. K. Phoon, D. W. Hight and S. Leroueil), London, UK: Taylor and Francis Group.

Lehane, B. M. \& Jardine, R. J. (2003). Effects of long-term pre-loading on the performance of a footing on clay. Géotechnique 53, No. 8, 689-695, http://dx.doi.org/10.1680/geot.2003.53.8.689.

Lunne, T., Robertson, P. K. \& Powell, J. J. M. (1997). Cone penetration testing in geotechnical practice. London, UK: Blackie Academic and Professional.

Mesri, G. \& Ajlouni, M. (2007). Engineering properties of fibrous peats. J. Geotech. Geoenviron. Engng 133, No. 7, 850-866.

Yamaguchi, H., Ohira, Y., Kogure, K. \& Mori, S. (1985). Undrained shear characteristics of normally consolidated peat under triaxial compression and extension. Soils Found. 25, No. 3, 1-18.

Zdravkovic, L. \& Jardine, R. J. (2001). The effect on anisotropy of rotating the principal stress axes during consolidation. Géotechnique 51, No. 1, 69-83, http://dx.doi.org/10.1680/geot.2001. 51.1.69.

Zwanenburg, C., Den Haan, E. J., Kruse, G. A. M. \& Koelewijn, A. R. (2012). Failure of a trial embankment on peat in Booneschans, the Netherlands. Géotechnique 62, No. 6, 479-490, http://dx.doi.org/10.1680/geot.9.P.094. 